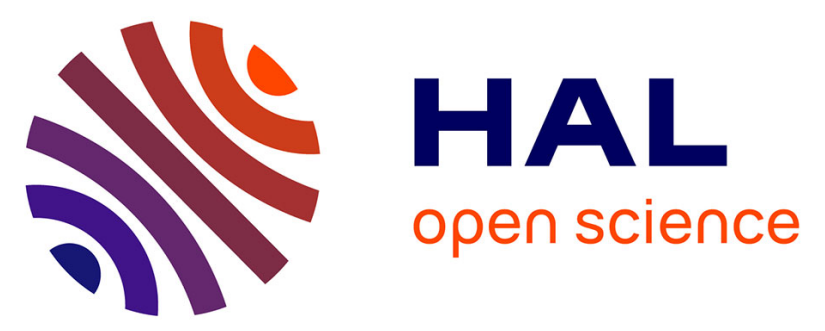

\title{
An assessment of contaminant concentrations in toothed whale species of the NW Iberian Peninsula: Part II. Trace element concentrations
}

Paula Méndez-Fernandez, Lynda Webster, Tiphaine Chouvelon, Paco Bustamante, Marisa Ferreira, Angel González, Alfredo López, Colin Moffat, Graham Pierce, Fiona Read, et al.

\section{To cite this version:}

Paula Méndez-Fernandez, Lynda Webster, Tiphaine Chouvelon, Paco Bustamante, Marisa Ferreira, et al.. An assessment of contaminant concentrations in toothed whale species of the NW Iberian Peninsula: Part II. Trace element concentrations. Science of the Total Environment, 2014, 484, pp.206 - 217. 10.1016/j.scitotenv.2014.03.001 . hal-01079869

\section{HAL Id: hal-01079869 https://hal.science/hal-01079869}

Submitted on 3 Nov 2014

HAL is a multi-disciplinary open access archive for the deposit and dissemination of scientific research documents, whether they are published or not. The documents may come from teaching and research institutions in France or abroad, or from public or private research centers.
L'archive ouverte pluridisciplinaire HAL, est destinée au dépôt et à la diffusion de documents scientifiques de niveau recherche, publiés ou non, émanant des établissements d'enseignement et de recherche français ou étrangers, des laboratoires publics ou privés. 
An assessment of contaminant concentrations in toothed whale species of the NW Iberian Peninsula: Part II. Trace element concentrations

Paula Méndez-Fernandez ${ }^{\mathrm{a}, \mathrm{b}, \mathrm{c}^{*}}$, Lynda Webster $^{\mathrm{d}}$, Tiphaine Chouvelon ${ }^{\mathrm{a}}$, Paco Bustamante ${ }^{\mathrm{a}}$, Marisa Ferreira $^{c}$, Angel F. González ${ }^{\mathrm{e}}$, Alfredo López ${ }^{\mathrm{b}}$, Colin F. Moffat ${ }^{\mathrm{d}}$, Graham J. Pierce ${ }^{\mathrm{f}, \mathrm{g}}$, Fiona L. Read ${ }^{\mathrm{e}}$, Marie Russell ${ }^{\mathrm{d}}$, Maria B. Santos ${ }^{\mathrm{h}}$, Jérôme Spitz ${ }^{\mathrm{a}, \mathrm{i}}$, José V. Vingada ${ }^{\mathrm{c}, \mathrm{g}}$, Florence Caurant ${ }^{\mathrm{a}}$

${ }^{a}$ Littoral Environment et Sociétes (LIENSs), UMRi 7266 CNRS-Université de La Rochelle, 2 Rue Olympe de Gouges, 17042 La Rochelle Cedex 01, France

${ }^{b}$ Coordinadora para o Estudo dos Mamiferos Mariños (CEMMA), Apdo. 15, Pontevedra, 36380, Spain

${ }^{c}$ Centro de Biologia Molecuar e Ambiental (CBMA)/Sociedade Portuguesa de Vida Selvagem (SPVS). Dep. de Biologia, Universidade do Minho, Campus de Gualtar, Braga, 4710-057, Portugal

${ }^{d}$ Marine Scotland, Marine Laboratory, Victoria Road, Aberdeen AB11 9DB, United Kingdom ${ }^{e}$ Instituto de Investigaciones Marinas (C.S.I.C), Eduardo Cabello 6, 36208, Vigo, Spain

${ }^{f}$ Oceanlab, University of Aberdeen Main Street, Newburgh, Aberdeenshire, AB41 6AA, UK

${ }^{g}$ Centre for Environmental and Marine Studies (CESAM), Universidade de Aveiro, Campus Universitário de Santiago, 3810-193 Aveiro, Portugal

${ }^{h}$ Instituto Español de Oceanografía, Centro Oceanográfico de Vigo, P.O. Box 1552, Vigo, 36200, Spain

${ }^{i}$ Marine Mammal Research Unit, Fisheries Centre, University of British Columbia, 2202 Main Mall, Vancouver, British Columbia V6T 1Z4, Canada

*Corresponding author at: Littoral Environment et Sociétes (LIENSs), UMRi 7266 CNRSUniversité de La Rochelle, 2 Rue Olympe de Gouges, 17042 La Rochelle Cedex 01, France. Tel: +33 5 46458388; fax: +33546496711 E-mail address: paula.mendez_fernandez@outlook.com (P. Méndez-Fernandez) 


\begin{abstract}
Concentrations of $\mathrm{Ag}, \mathrm{As}, \mathrm{Cd}, \mathrm{Co}, \mathrm{Cr}, \mathrm{Cu}, \mathrm{Fe}, \mathrm{Hg}, \mathrm{Mn}, \mathrm{Ni}, \mathrm{Pb}, \mathrm{Se}, \mathrm{V}$ and $\mathrm{Zn}$ were investigated in liver and kidney of the five most common toothed whales off the Northwest Iberian Peninsula (NWIP), specifically common dolphin, long-finned pilot whale, harbour porpoise, striped dolphin and bottlenose dolphin. Differences were observed in the bioaccumulation of the above elements between the five species. The differences are probably related to biological factors such as age and sex and/or to ecological factors specific to each species such as feeding habits or bioavailability of the various elements. However, no significant relationship was observed between element accumulation and sex. Pilot whale and striped dolphin showed the highest concentrations of renal $\mathrm{Cd}$ and the highest concentrations of hepatic $\mathrm{Hg}$ and $\mathrm{Se}$, while bottlenose dolphin showed the highest concentrations of $\mathrm{Hg}$ in kidneys. An analysis of inter-elemental relationships showed strong positive correlations between $\mathrm{Hg}$ and $\mathrm{Se}$ in the five species, however most individuals have $\mathrm{Hg}$ :Se molar ratio less than 1:1 indicating an excess of Se compare to $\mathrm{Hg}$. This result, probably reflect the high proportion of young animals in the sample available for this study and/or that these animals had a good health status. We also observed a positive correlation in striped dolphins between $\mathrm{Cd}$ and $\mathrm{Cu}$ and between $\mathrm{Cd}$ and $\mathrm{Zn}$ in kidneys. In addition, comparing with other studies world-wide, the element concentrations ( $\mathrm{Hg}$ and $\mathrm{Cd}$ ) found in Iberian toothed whales indicates that these populations are not specially threatened by $\mathrm{Hg}$ and $\mathrm{Cd}$ exposure in the area.
\end{abstract}

Keywords: trace elements; bioaccumulation; toothed whales; Northwest Iberian Peninsula 


\section{Introduction}

A better understanding of marine mammal ecology and physiology, including changes related to anthropogenic activities such as concentrations of chemical contaminants, is needed. Specifically there is a requirement to clarify the significance of contaminants in the wellbeing of marine mammal populations and the possibility of population level impacts from contaminants, with the objective of improved protection for these apex species. In Europe, recent legislation has been implemented with the aim of protecting and restoring ecological quality or integrity in estuarine and marine coastal and offshore systems (e.g. Water Framework Directive (WFD), Marine Strategy Framework Directive (MSFD), Habitats Directive) in which cetaceans are specifically recognised as an important component.

The Northwest Iberian Peninsula (NWIP) is situated at the northern limit of the NW African upwelling system (Figueiras et al., 2002). During the summer, the prevalent northerly winds favour the upwelling of nutrient-rich Eastern Atlantic Central Water (ENACW) that in turn sustains a high productivity and a considerable biodiversity. Nearly 300 species of fish, 78 species of cephalopods and at least 16 species of marine mammals have been reported in the area (Penas-Patiño and Piñeiro-Seage, 1989; Fernández de la Cigoña, 1990; Guerra, 1992). During the last decades, industrial development and an increase in other human marinerelated activities in the area have intensified the pressures on the marine environment. To monitor the level of contamination, analyses of samples of sediments, seawater and commercial species such as shellfish are routinely carried out (e.g. Carro et al., 2002; Prego et al., 2003). In addition, the monitoring of contaminants in the area increased after the Prestige tanker spill on $19^{\text {th }}$ November 2002 (e.g. Prego and Cobelo-García, 2004; Junoy et al., 2005; Pérez-López et al., 2006; Moreno et al., 2011; Romero et al., 2012). The presence of potentially toxic substances has occasionally been investigated in marine mammals from the NWIP since the 1980s (e.g. Borrell et al., 2001, 2006; Zegers et al., 2005; Pierce et al., 2008; Murphy et al., 2010).

In contrast to most organic chemicals, trace elements occurring in the marine environment are derived from both natural and anthropogenic (e.g. mining and industrial discharges) sources. Trace elements can be divided into essential elements and non-essential elements. The essential elements include $\mathrm{Cu}, \mathrm{Zn}$, Se; these have a biological function. The non-essential elements include $\mathrm{Hg}, \mathrm{Cd}, \mathrm{Pb}$ ). Many of these are potentially toxic, even at low concentrations (Chappuis et al., 1991). Marine mammals, as long-lived apex predators, are potentially threatened by non-essential trace elements, since most are bioaccumulated and biomagnified through food webs (Law, 1996; Das et al., 2003a). Their distribution in tissues basically 
follows their chemical affinities. $\mathrm{Hg}, \mathrm{Cu}, \mathrm{Zn}$ and other elements exhibit the higher concentrations in liver, $\mathrm{Cd}$ accumulates in kidney and $\mathrm{Pb}$ in bones (Honda et al., 1982; André et al., 1990a, 1990b).

The actual toxic effects of trace elements remain unclear since marine mammals have been exposed to these natural compounds for a very long time in evolutionary terms and as such have developed mechanisms to control and/or mitigate their toxic effects (Law, 1996; Gallien et al., 2001; Vos et al., 2003). As an example, the detoxification process of methylmercury by selenium through the formation of tiemanite in the liver (Koeman et al., 1973; Martoja and Berry, 1980) leads to high concentrations of $\mathrm{Hg}$, especially in toothed whales, without any obvious toxic effects (e.g. Koeman et al., 1973; Julshamn et al., 1987; Caurant et al., 1996; Nyman et al., 2002). Nevertheless, non-essential elements are more frequently monitored because of their threat and toxicity (O'Shea, 1999) and surrogate values from terrestrial mammals are used to evaluate their health effects on marine mammal populations.

The concentration of contaminants in marine mammal tissues varies primarily in relation to the prey they consume, but is also a function of their capacity to excrete these elements (Aguilar et al., 1999). Several biological factors have also been found to affect variations in trace element concentrations in marine mammals. These include, in particular, age (André et al., 1990a, 1990b) but also body size and composition, nutritive condition, sex, health status, reproductive status/history duration of lactation and/or toxicodynamic and toxicokinetic processes (e.g. Muir et al., 1988; Caurant et al., 1994; Das et al., 2003a). Therefore, these factors have to be carefully taken into account when interpreting contaminant concentrations and their potential effects.

This paper constitutes the part II of a two-part series; in this second part we extend the assessment of contamination status of the five most common cetacean species in the NWIP waters, initiated in part I (Méndez-Fernandez et al., submitted), comparing our results with data from previous studies on trace elements across the world and also including species from this geographic area that had not been previously analysed, such as the pilot whale. To this aim the liver and kidney of a total of 172 individuals were analysed for 14 trace elements: silver $(\mathrm{Ag})$, arsenic $(\mathrm{As})$, cadmium $(\mathrm{Cd})$, cobalt $(\mathrm{Co})$, chrome $(\mathrm{Cr})$, copper $(\mathrm{Cu})$, iron $(\mathrm{Fe})$, manganese $(\mathrm{Mn})$, nickel $(\mathrm{Ni})$, lead $(\mathrm{Pb})$, selenium $(\mathrm{Se})$, vanadium $(\mathrm{V})$ and zinc $(\mathrm{Zn})$. To evaluate their trace element contamination status in the area we also compare trace element patterns among the five species studied. Finally, the Spearman correlation coefficient test was calculated in order to determine any co-linearity between concentrations of different trace 
elements focusing on $\mathrm{Cu}, \mathrm{Se}$ and $\mathrm{Zn}$ since they are known to participate in the $\mathrm{Cd}$ and $\mathrm{Hg}$ detoxification processes.

\section{Materials and methods}

\subsection{Sampling and study area}

Sampling was carried out in the NWIP, from the northern limit of the Galician coast in Spain $\left(43^{\circ} 3^{\prime} \mathrm{N}, 7^{\circ} 2^{\prime} \mathrm{W}\right)$ to Nazaré on the Portuguese coast $\left(39^{\circ} 36^{\prime} \mathrm{N}, 9^{\circ} 3^{\prime} \mathrm{W}\right)$ during 2004 to 2008 (Fig. 1). Experienced members of the Spanish (Coordinadora para o Estudo dos Mamiferos Mariños, CEMMA) and Portuguese (Sociedade Portuguesa de Vida Salvagem, SPVS) stranding networks have been attending stranded and by-caught cetaceans for more than a decade and two decades respectively. Animals were identified to species, measured, sexed and, if the decomposition state of the carcass allowed, full necropsies were performed and samples were collected whenever possible. All procedures followed the standard protocol defined by the European Cetacean Society (ECS) including the decomposition state condition code (Kuiken and Garcia Hartmann, 1991). The animals recovered in a "fresh" state (a score of 1 to 3 from the ECS protocol, i.e. originally stranded alive, freshly dead or mildly decomposed) were selected. The common dolphin Delphinus delphis is the most frequently cetacean species in this area, which is believed to be a direct result of the large number of individuals being by-caught in NWIP fisheries (López et al., 2002, 2003), and therefore is the best represented species in the samples analysed $(n=114)$, but smaller numbers of four other species were also available: long-finned pilot whale Globicephala melas, $\mathrm{n}=9$; harbour porpoise Phocoena phocoena, $\mathrm{n}=19$; striped dolphin Stenella coeruleoalba, $\mathrm{n}=21$ and bottlenose dolphin Tursiops truncatus, $\mathrm{n}=9$.

Teeth were collected for age determination and liver and kidneys for trace element analyses. After the necropsies, all samples of liver and kidneys for trace element analyses were removed and stored in polyethylene bags and stored frozen at $-20^{\circ} \mathrm{C}$ until required for analysis.

\subsection{Determination of age}

At least five teeth were collected from each sampled individual, selecting the least worn/damaged and least curved teeth, to ensure sufficient material for replicate preparations. Teeth were preserved frozen or in $70 \%$ alcohol. Age was determined by analyzing growth layer groups (GLGs) in the dentine of the teeth, following methods adapted from Lockyer (1993), Hohn and Lockyer (1995) and Rogan et al. (2004). In brief, teeth were decalcified and then sectioned using a cryostat. The most central and complete sections (including the whole 
pulp cavity) were selected from each tooth, stained with Mayer's haematoxylin (modified by Grue) and 'blued' in a weak ammonia solution, then mounted on glass slides and allowed to dry. GLGs were counted under a binocular microscope. All readings were initially made blind (i.e. without access to individual biological data) and replicate counts were made by two independent readers.

\subsection{Determination of trace elements}

All the equipment used in the sample processing was cleaned, and subsequently decontaminated for $24 \mathrm{~h}$ in a solution composed of $35 \mathrm{~mL} \mathrm{HNO}_{3}(65 \%)$ and $50 \mathrm{~mL} \mathrm{HCl}$ (36\%) mixed into $1 \mathrm{~L}$ of Milli-Ro quality water. Frozen liver and kidney samples were freezedried and ground to powder using a Planetary Ball Mills Retsch PM 200. Two replicates for each sample were prepared for trace element analyses.

$\mathrm{Ag}, \mathrm{As}, \mathrm{Cd}, \mathrm{Co}, \mathrm{Cr}, \mathrm{Cu}, \mathrm{Fe}, \mathrm{Mn}, \mathrm{Ni}, \mathrm{Pb}, \mathrm{Se}, \mathrm{V}$ and $\mathrm{Zn}$ analyses were performed with a Varian Vista-Pro for Inductively Coupled Plasma Atomic Emission Spectrophotometry (ICP-AES) and a Thermofisher Scientific XSeries 2 for Inductively Coupled Plasma Mass Spectrometry (ICP-MS). Total Hg was determined using an Advanced Mercury Analyser (Altec AMA 254). For ICP-AES and ICP-MS measurements, aliquots of dried samples, from 0.1 to $0.3 \mathrm{~g}$, were

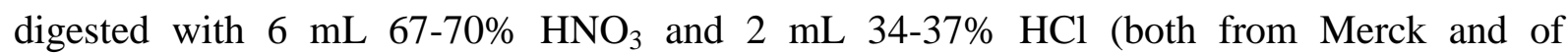
Suprapur ${ }^{\circledR}$ quality). Acid digestion of the samples was carried out overnight at room temperature and then in a Milestone microwave oven. The oven temperature was increased over a period of $30 \mathrm{~min}$ up to a final temperature of $120^{\circ} \mathrm{C}$. The temperature was maintained at this maximal value for 15 minutes. After digestion, each sample was made up to a final volume of $50 \mathrm{~mL}$ with milli-Q water. For samples with a weight $<0.1 \mathrm{~g}$, the mixture used was $3 \mathrm{~mL} 67-70 \% \mathrm{HNO}_{3} / 1 \mathrm{~mL} 34-37 \% \mathrm{HCl}$ and the samples were diluted to a final volume of 25 mL milli-Q water.

Mercury analysis was carried out with an Automatic Mercury Analyser spectrophotometer, ALTEC AMA 254 (AAS), which does not require an acid-digestion of the samples. Aliquots of $5 \pm 0.5 \mathrm{mg}$ dried sample were directly analysed after being inserted in the oven of the apparatus. After drying, the samples were heated under an oxygen atmosphere for $3 \mathrm{~min}$, and the $\mathrm{Hg}$ liberated and subsequently amalgamated on an Au-net. The net was then heated to liberate the collected $\mathrm{Hg}$, which was measured by AAS.

All trace element concentrations in tissues are reported in $\mu \mathrm{g} \mathrm{g}^{-1}$ wet weight (wet wt.).

\subsection{Quality control}

All methods were validated by the replicate analysis of standards and samples, and through spiking experiments or analysis of certified reference materials (CRMs). For trace elements, 
two CRMs and three to six blanks, treated and analysed in the same way as the samples, were included in each analytical batch. The CRMs were DOLT-4 (dogfish liver; National Research Council Canada [NRCC]) and TORT-2 (lobster hepatopancreas; NRCC). For all trace elements the measurement were in satisfactory agreement with the given certified values and showed mean recoveries of $94.5 \%$ for DOLT-4 and $97.5 \%$ for TORT-2. The limits of detection (LODs) $\left(\mu \mathrm{g} \mathrm{g}^{-1}\right.$ wet wt.) were 0.07 for $\mathrm{Ag}, \mathrm{Cd}, \mathrm{Co}, \mathrm{Cr}$ and $\mathrm{Pb} ; 0.67$ for $\mathrm{As} ; 0.2$ for $\mathrm{Ni}$; 0.35 for Se; 1.0 for $\mathrm{V} ; 2.5$ for $\mathrm{Cu}$ and $\mathrm{Mn} ; 13$ for Fe and $\mathrm{Zn}$; 0.002 for Hg. Finally, these protocols were validated by an international intercalibration exercise (Christopher et al., 2007).

\subsection{Data treatment}

All data submitted to statistical tests were first checked for normality (Shapiro-Wilk test) and for homogeneity of variances (Bartlett test). When these conditions were satisfied, parametric tests were performed in the subsequent analyses; otherwise, data were transformed or nonparametric tests were used.

Variation in log-transformed trace element concentrations in toothed whales was investigated using analysis of covariance (ANCOVA). As age is an important factor influencing the accumulation of trace elements (Aguilar et al., 1999), this parameter was used as the covariate in the ANCOVA to determine the influence of gender and species. When significant betweenspecies variation was detected, the ANCOVA was followed by Tukey multi-comparison tests to evaluate differences between each pair of species. In addition, discriminant analysis (DA) was used to examine differences in the trace element patterns among the species. As for ANCOVA analysis, only elements with concentrations above the limit of detection (see Table 1) were included in the DA.

Finally, the Spearman correlation coefficient test was calculated in order to determine any colinearity between concentrations of different trace elements. We focussed on $\mathrm{Cu}, \mathrm{Se}$ and $\mathrm{Zn}$ since they are known to participate in the $\mathrm{Cd}$ and $\mathrm{Hg}$ detoxification processes. In addition, we evaluated the $\mathrm{Hg}$ detoxification process through the calculation of the $\mathrm{Hg}$ :Se molar ratio. This ratio was calculated as: $\mathrm{Hg}: \mathrm{Se}=\left(\mathrm{Hg}\left(\mu \mathrm{g} \mathrm{g}^{-1}\right.\right.$ wet wt. $) / \mathrm{Se}\left(\mu \mathrm{g} \mathrm{g}^{-1}\right.$ wet wt. $\left.)\right) \times\left(78.96\left(\mathrm{~g} \mathrm{~mol}^{-}\right.\right.$ $\left.\left.{ }^{1}\right) / 200.59\left(\mathrm{~g} \mathrm{~mol}^{-1}\right)\right)$, where $200.59 \mathrm{~g} \mathrm{~mol}^{-1}$ and $78.96 \mathrm{~g} \mathrm{~mol}^{-1}$ are the atomic mass of $\mathrm{Hg}$ and Se, respectively.

The levels of significance for statistical analyses were always set at $\alpha=0.05$ and analysis were performed using R version 2.11.1 (R Development Core Team, 2010). 


\section{Results and discussion}

\subsection{Concentrations of trace elements in the light of biological and ecological factors}

Trace element concentrations in the tissues of marine mammals are well-documented on a global basis, with a focus on the non-essential elements $\mathrm{Cd}$ and $\mathrm{Hg}$, and the essential ones, $\mathrm{Cu}, \mathrm{Zn}$ and $\mathrm{Se}$ for their role in the detoxification of $\mathrm{Cd}$ and $\mathrm{Hg}$. However, few studies have investigated the wider range of trace elements present in the liver and kidney of marine mammals as studied here (e.g. Bustamante et al., 2003; Bryan et al., 2007; Griesel et al., 2008; Stavros et al., 2008). The reason is probably that the trace elements analyzed are either not bioaccumulated in large amounts in mammalian tissues (Thompson, 1990); or liver and kidney are not the organs of storage for some of them. In humans, for example, baseline data on As, $\mathrm{Ag}, \mathrm{Co}, \mathrm{Cr}, \mathrm{Mn}, \mathrm{Ni}$ or $\mathrm{V}$ is effectively more often available in blood than in tissues, and recent studies in marine mammals that have investigated as many or even more trace elements than in this study, dealt with blood or skin as non invasive monitoring samples (Bryan et al., 2007; Griesel et al., 2008; Stavros et al., 2008).

The trace elements analysed exhibit different status. $\mathrm{Cd}, \mathrm{Pb}, \mathrm{Hg}$ and $\mathrm{Ag}$ are toxic elements for which no biological function has been demonstrated so far. In contrast, $\mathrm{Fe}, \mathrm{Cu}, \mathrm{Co}, \mathrm{Zn}, \mathrm{Se}$ and $\mathrm{Cr}$ are essential elements whose deficiency induces pathology in human and more generally in mammals (Chappuis, 1991; Underwood, 1977). The status of As depend on the physicochemical forms to which mammals are exposed. In humans, the toxicological risk of As is due to inorganic forms to which they can be exposed in occupational situations. In the marine environment, tissues of marine invertebrates and fish contain high concentrations of As (1 to $100 \mu \mathrm{g} \mathrm{g}^{-1}$ dry wt.) in the form of organoarsenic compounds, particularly arsenobetaine (Neff, 1997). Our results revealed that concentrations of the essential elements $\mathrm{Co}, \mathrm{Pb}$ and $\mathrm{V}$ were below the detection limit in all species for both kidney and liver, while the concentrations of Ag and Mn were below the detection limit in kidney for all species (Table 1). Concerning As, only pilot whale and bottlenose dolphin exhibited detectable concentrations of this element and probably as a consequence of a higher exposure through their diet. Kubota et al. (2001) suggest that cetacean feeding on cephalopods and crustaceans leads to higher retention of As concentration than a piscivorous diet, which is the case of pilot whales. The remaining elements being above the detection limit could be categorized into two distinct groups, within which the patterns were generally similar across all species. Four of the elements $(\mathrm{Cu}, \mathrm{Fe}, \mathrm{Hg}$ and $\mathrm{Se}$ ) exhibited higher concentrations in liver than in kidney (see $\mathrm{Hg}$ shown as an example in Fig. 2a). In contrast, $\mathrm{Cd}, \mathrm{Cr}$ and $\mathrm{Ni}$ showed lower concentrations in the liver compared to kidney (see example of Cd, Fig. 2b). 
One characteristic of essential elements in marine mammal tissues is that they are regulated through homeostasis. The processes leading to homeostatic control include regulation of intestinal absorption and/or biliary and urinary excretion. As a consequence, essential trace elements are generally not bioaccumulated with age. This fact explains the lack of a significant effect of age (ANCOVA, $P>0.05$ ) found in this study on renal $\mathrm{Cr}$, Se and $\mathrm{Zn}$ and for hepatic $\mathrm{Cu}, \mathrm{Fe}$ and $\mathrm{Zn}$, all essential elements (Table 2). Conversely, concentrations of nonessential trace elements have been reported to increase with age in several cetacean species and across various geographical areas, especially the most studied elements, $\mathrm{Hg}$ and $\mathrm{Cd}$ (Honda et al., 1983; Caurant et al., 1994; Bustamante et al., 2004; Lahaye et al., 2006, 2007). Both of them probably accumulate because uptake exceeds the ability of the animal to excrete these elements. Consequently, concentrations will increase with age in the respective storage tissues, liver for $\mathrm{Hg}$ and kidney for $\mathrm{Cd}$. However, the kinetics of accumulation seems to differ between $\mathrm{Hg}$ and $\mathrm{Cd}$, while remaining similar across species: $\mathrm{Hg}$ bioaccumulation occurs throughout the life of individuals, while $\mathrm{Cd}$ reaches a plateau after several years, more or less rapidly according to the species (Aguilar et al., 1999; Caurant et al., 1994; Bustamante et al., 2004). Only hepatic Hg showed a lack of a significant age effect on concentration in this study (Table 2); this counterintuitive result could be the consequence of the high number of young individuals in our sample set.

Sex is another biological factor that can have an influence on trace element burdens in marine mammals, and specifically reproductive activities such as pregnancy, parturition and lactation (Honda et al., 1987). In addition, differences in prey preferences and in feeding areas between females and males may affect trace element burdens (Gochfeld et al., 1997). However, the influence of sex on trace element concentrations measured in marine mammals is not wellunderstood and it seems to vary with the element, the tissue and the species analysed (Honda et al., 1987; Canella and Kitchener, 1992; Wagemann et al., 1995; Aguilar et al., 1999). In this study there was no influence of sex, except male common dolphin showing higher renal Cd concentrations than females $(P<0.05)$.

Several different routes of entry of trace elements have been suggested in marine mammals: uptake from the atmosphere, absorption through the skin or across the placenta, by ingestion of seawater and ingestion of food including milk for calves (e.g., Caurant et al., 1994; Wagemann et al., 1995; Law, 1996; Lahaye et al., 2007). However, the main route seems to be via food (André et al., 1990a, 1990b; Law, 1996). As a consequence of this, the trophic ecology of species also has an important influence on trace element concentrations. In this study, we obtained significant differences (ANCOVA, $P<0.05$, Table 2) between species for 
all trace elements in at least one of the two tissues analysed (for trace elements being above the detection limit). Pilot whale and striped dolphin exhibited the highest $\mathrm{Cd}$ concentrations in both liver and kidney (see Table 1). This result is in line with the similar feeding patterns of these species since both species primarily feed in offshore waters and have a high proportion of oceanic squid in their diet (Spitz et al., 2006, 2011; Santos et al., 2013a; 2013b). Squid are known to accumulate large amounts of cadmium and to be the major source of $\mathrm{Cd}$ in top predators (Bustamante et al., 1998; Lahaye et al., 2005). Pilot whale, striped and bottlenose dolphins also showed the highest $\mathrm{Hg}$ concentrations in liver and in kidney (Table 1). Such $\mathrm{Hg}$ accumulation in species having different feeding preferences (fish $v s$ cephalopods) is consistent with the high bioavailability of $\mathrm{Hg}$ for upper trophic levels in both fish and cephalopods (Bloom, 1992; Bustamante et al., 2006), and not only on fish prey as was previously thought. Indeed, Atlantic striped dolphins also consumed mesopelagic fishes, such as Myctophids (lanternfish) and Sternoptychids (small deep-sea ray-finned fish) (Ringelstein et al., 2006; Spitz et al., 2006), and these mesopelagic fish from Atlantic waters are well known to also exhibit high Hg concentrations (Monteiro et al., 1996; Thompson et al., 1998; Lahaye et al., 2006; Chouvelon et al., 2012).

The influence of trophic ecology and biological process in trace elements accumulation is confirmed by the discriminant analysis performed (Fig. 3). In fact, harbour porpoise (Pph in Fig. 3) appear distinct from the other species with a focus on the upper left portion of the plot (low LD1, high LD2). This species is the most frequently observed near to the coast and mainly feeds on fish species in the NWIP (Santos and Pierce, 2003; López et al., 2004; Pierce et al., 2010). On the lower right portion there are the oceanic and teuthophagous species, striped dolphin (Sco in Fig. 3) and pilot whale (Gme in Fig. 3), which have the highest $\mathrm{Hg}$ and Cd concentrations in this study. Finally, common and bottlenose dolphin appear not to gathered out and are in the centre of the individual clouds, coinciding with their intermediate position in terms of diet (fish and cephalopods consumption), and habitat (oceanic and coastal) among the five species in the area (López et al., 2004; Santos et al., 2004, 2007; Pierce et al., 2010). The main elements forcing separation along the canonical axis 1 were renal $\mathrm{Cu}$, renal Se, hepatic $\mathrm{Cd}$ and hepatic and renal $\mathrm{Cr}$. Along canonical axis 2, the most important elements determining separation were hepatic $\mathrm{Ag}$, hepatic and renal $\mathrm{Cr}$ and renal $\mathrm{Cu}$. These findings reflect distinct trace element accumulation patterns in toothed whales from the NWIP, which can be determined by factors such as diet and habitat use, as well as by different biological processes for the species. Moreover, these results are consistent with the PCB patterns obtained in the first part of this study (Méndez-Fernandez et al., submitted); the 
pilot whale and the striped dolphin had a higher proportion of less chlorinated congeners than the other three species, which showed a higher proportion of the higher chlorinated PCB congeners. Finally, these results are also highly consistent with the niche segregation among these toothed whales in the NWIP by using $\mathrm{Cd}$, carbon and nitrogen isotopes as ecological tracers (Méndez-Fernandez et al., 2013).

\subsection{Interelemental relationships}

The inter-specific differences in essential trace element concentrations are more intriguing than for the non-essential ones since, as discussed above, they indicate that homeostatic processes probably differ between the species. These different concentrations of essential elements could also be correlated to the concentrations of non-essential elements in the wellknown detoxification processes. For this reason correlations between trace elements known to participate in the $\mathrm{Cd}$ and $\mathrm{Hg}$ detoxification processes were tested within each species separately (Table 3). Hepatic $\mathrm{Hg}$ and Se were positively correlated in the five species while renal $\mathrm{Hg}$ and Se were positively correlated in common, striped and bottlenose dolphin. A positive correlation between $\mathrm{Hg}$ and Se has been largely described (Koeman et al., 1973, 1975; Pelletier, 1985; Cuvin-Aralar and Furness, 1991) and it is known as a detoxification process that provides protection against high $\mathrm{Hg}$ concentrations through the formation of tiemannite (Martoja and Berry, 1980). A 1:1 Hg:Se molar ratio would indicate that almost all available $\mathrm{Se}$ is bound to $\mathrm{Hg}$. Owing to the oxy-radical scavenging involvement of Se, tissue ratios close to 1:1 could indicate compromised health (Dietz et al., 2000). Overall we observed that over a concentration of $5 \mathrm{nmol} \mathrm{g}^{-1}$ of $\mathrm{Hg}$ values are close to the Se:Hg molar ratio of 1 (Fig. 4). However, below this value of $5 \mathrm{nmol} \mathrm{g}^{-1}$ the variability of the molar ratio is important, indicating an excess of Se compared to $\mathrm{Hg}$ and thus also its bioavailability for other functions. In fact, only $2.6 \%$ of the individuals showed a $\mathrm{Hg}$ :Se ratio > 1.0. One of these individuals was an immature common dolphin with a high $\mathrm{Hg}$ concentration of $303.9 \mu \mathrm{g}$ $\mathrm{g}^{-1}$ wet wt. Thus, considering $\mathrm{Hg}$ :Se ratio, $\mathrm{Hg}$ is probably not the main threat for most of the Iberian toothed whales. However, it is important to note the high proportion $(\sim 70 \%)$ of immature individuals in the sampled population.

In addition, it has been shown that the essential elements $\mathrm{Cu}$ and $\mathrm{Zn}$ are commonly related to Cd detoxification (Das et al., 2000a) by induction of metallothioneins (MTs) (Wagemann et al., 1988; Teigen et al., 1999). These proteins, which play a role in the homeostasis of the essential elements (such as $\mathrm{Cu}$ and $\mathrm{Zn}$ ), are induced by $\mathrm{Cd}$ as well as other trace elements (Engle and Brouwer, 1989; George and Olsson, 1994). Here, Zn was significantly correlated with $\mathrm{Cd}$ in both tissues of striped dolphins (Spearman correlation, $r=-0.509$ in 
liver and $r=0.681$ in kidney, $P<0.05$, Table 3), and this species was the one exhibiting the highest Cd concentrations (Table 2). There is also a positive correlation between renal $\mathrm{Cd}$ and $\mathrm{Cu}$ concentrations in striped dolphins (Spearman correlation, $r=0.235, P<0.05$ ) and between hepatic $\mathrm{Cd}$ and $\mathrm{Cu}$ in common dolphins (Spearman correlation, $r=0.203, P<0.05$ ). However, the high Cd concentrations observed in pilot whales from the NWIP, which are the highest concentrations among the five species studied (Table 2), are probably not sufficient to induce $\mathrm{Cu}$ or/and $\mathrm{Zn}$ ion displacement from MTs, and consequently leading to coaccumulation with $\mathrm{Cd}$ in this species.

\subsection{Geographic comparison}

Data obtained for hepatic $\mathrm{Hg}$ and renal Cd concentrations for the five toothed whales in this study are compared with those reported previously all over the world and presented in Table 4. Overall, hepatic $\mathrm{Hg}$ and renal $\mathrm{Cd}$ concentrations of Iberian common dolphins were of the same order of magnitude than those reported by previous studies on adjacent areas of the NE Atlantic Ocean; however they are smaller than those reported in the Mediterranean Sea, in the western part of the Atlantic Ocean, and in the Pacific and Indian Ocean. The hepatic $\mathrm{Hg}$ concentrations of Iberian pilot whales are much smaller than those from northern latitudes of the NE Atlantic Ocean, but also smaller than in the western part of the Atlantic Ocean and than in the Pacific Ocean. For Cd the differences observed among areas are smaller than for $\mathrm{Hg}$ concentrations, however the northern latitudes still having greater concentrations. This result is not surprising and confirms results from various studies on the $\mathrm{Cd}$ and $\mathrm{Hg}$ in marine mammals from Arctic and temperate regions, which indicates that animals from lower latitude display far lower $\mathrm{Cd}$ and $\mathrm{Hg}$ levels in their tissues, despite a higher anthropogenic influence (Paludan-Müller et al., 1993; Szefer et al., 2002; Bustamante et al., 2004; Das et al., 2004a).

Hepatic $\mathrm{Hg}$ concentrations in Iberian porpoises were globally in the same range of concentrations as porpoises from the adjacent waters of the Atlantic Ocean, with the exception of individuals from south England and Irish Sea with means of 22 and $30 \mu \mathrm{g} \mathrm{g}^{-1}$ wet wt., respectively, compared with the $16.8 \mu \mathrm{g} \mathrm{g}^{-1}$ wet wt. from the Iberian porpoises. In contrast, lower $\mathrm{Hg}$ concentrations have been reported for porpoises from the North Sea, Iceland and Greenland (Table 4). Furthermore, and contrary to $\mathrm{Hg}$, Iberian porpoises showed the highest concentrations from all the areas compared, with the exception of Iceland, and especially, Greenland porpoises. In fact, Cd levels are well-known to be elevated in arctic sediments and organisms (e.g. MacDonald and Sprague, 1988; AMAP, 1998; Dietz et al., 1998), and especially in cephalopods (Bustamante et al., 1998). The squid biomass occurring in stomach contents is much higher in porpoises from Greenland than in porpoises from lower 
latitudes of European waters (Santos and Pierce, 2003), which could explain the higher renal Cd concentrations obtained in Greenland animals compared to Iberian animals.

Finally, striped and bottlenose dolphin showed hepatic Hg concentrations in the same order or magnitude as areas from the NW Atlantic however much smaller than dolphins from Mediterranean Sea, Adriatic Sea, SW Atlantic and Pacific Ocean, with some exceptions such as animals from France waters (Holsbeek et al., 1998; Lahaye et al., 2006). Higher Hg concentrations in Mediterranean organisms are typically explained by high temperature and absence of solar radiation in the deep environment that favors a high methylation rate. Moreover, in addition to industrial inputs, natural sources of $\mathrm{Hg}$ in the Mediterranean Sea may contribute to $\mathrm{Hg}$ enrichment through the benthic food webs, as it constitutes the richest natural reserve of this element (Bacci, 1989). Concerning renal Cd concentrations, unexpected high values were found in Iberian bottlenose dolphins (5.8 $\mu \mathrm{g} \mathrm{g}^{-1}$ wet wt.). As cephalopods constitutes a major source of Cd for cetaceans (Bustamante et al., 1998; Lahaye et al., 2005), low $\mathrm{Cd}$ concentrations would be expected in bottlenose dolphins as their diet is dominated by fish. Therefore, this result may be due to the higher concentrations of $\mathrm{Cd}$ in their environment, since upwelling waters, as for the NWIP, are known to have high inputs of this element (Boyle et al., 1976; 1988). However, this does not the case for striped dolphin which is a species that mainly feed on cephalopods in the NWIP but nevertheless shows lower values than dolphins from adjacent areas of the NW Atlantic Ocean. Thus, either there is a minor contribution of $\mathrm{Cd}$ in upwelling areas as we thought or the different feeding behavior of striped dolphins from Iberian waters and adjacent areas lead to a different $\mathrm{Cd}$ exposure for these animals (e.g. Ringelstein et al., 2006; Spitz et al., 2006; Santos et al., 2013b).

Overall, this comparison suggests that Iberian toothed whale populations are not specially threatened by $\mathrm{Hg}$ and $\mathrm{Cd}$ exposure in the area. Only porpoises showed slightly higher concentrations of both elements in comparison with other areas of the Atlantic waters but far below the suggested threshold levels of effects in humans and marine mammals for renal $\mathrm{Cd}$ (50 $\mu \mathrm{g} \mathrm{g}^{-1}$ wet wt.; Elinder and Järup, 1996 ) and hepatic $\mathrm{Hg}\left(61 \mu \mathrm{g} \mathrm{g}{ }^{-1}\right.$ wet wt.; Rawson et al., 1993).

\section{Conclusions}

The results of the present study revealed different degrees of exposure to trace elements among the five toothed whale species studied. This is a consequence of the influence of biological and ecological factors such as age, feeding habits and habitat used. However, no relationship was observed between element concentrations and sex. A strong positive 
correlation between $\mathrm{Hg}$ and $\mathrm{Se}$ in liver was observed for the five species, though the $\mathrm{Hg}: \mathrm{Se}$ molar ratio for most of the individuals analysed was less than 1:1, probably reflecting the high proportion of young animals in the sample available for this study and/or indicating that these animals had a good health status. In addition, comparing with other studies world-wide, the element concentrations ( $\mathrm{Hg}$ and $\mathrm{Cd}$ ) found in Iberian toothed whales indicates that these populations are not specially threatened by $\mathrm{Hg}$ and $\mathrm{Cd}$ exposure in the area.

Both parts of this study provide new information and complement the existing database on persistent organic pollutants and trace element concentrations in marine mammals of the NWIP. These data is central in a time when the European scientific community is developing research on large marine vertebrates as indicators of medium and long-term marine environmental change for incorporation under the EU Marine Strategy Framework Directive. In addition, it is extremely important for the environmental monitoring and for the conservation of these species in an area where surveillance regarding chemical contaminants continues. 


\section{Acknowledgments}

The authors gratefully acknowledge the assistance of volunteers from the Galician (CEMMA) and Portuguese (SPVS) stranding networks. They also thank C. Churlaud and M. Kalombo for running some of the metal analyses. This work was supported through the $\mathrm{PhD}$ grant of PMF from the Portuguese Foundation for Science and Technology of the Government of Portugal (SFRH/BD/36766/2007). GJP acknowledges support from the EU under the ANIMATE project (MEXC-CT-2006-042337). MBS was supported by the Spanish Ministry of Education, Programa Nacional de Movilidad de Recursos Humanos de Investigación (PR 2010- 0518) and the LOTOFPEL project (Plan Nacional de I + D + I, CTM 2010-16053). FLR acknowledges support from the EU under the ECOSUMMER project (MEST-CT-2005020501).

\section{References}

Aguilar A, Borrell A, Pastor T. Biological factors affecting variability of persistent pollutant levels in cetaceans. J Cetac Res Manage 1999;1:83-116.

AMAP (Arctic Monitoring and Assessment Programme). AMAP assessment report: arctic pollution issues, Chapter 7: Heavy metals. Arctic Monitoring and Assessment Programme, Oslo, 1998; p. 374-453.

André JM, Amiard JC, Amiard-Triquet C, Boudou M, Ribeyre F. Cadmium contamination of tissues and organs of delphinid species (Stenella atenuata) - influence of biological and ecological factors. Ecotoxicol Environ Saf 1990a;20:290-306.

André JM, Ribeyre F, Boudou A. Mercury contamination levels and distribution in tissues and organs of Delphinids (Stenella attenuata) from the eastern tropical pacific, in relation to biological and ecological factors. Mar Environ Res 1990b;30:43-72.

Andre J, Boudou A, Ribeyre F, Bernhard M. Comparative study of mercury accumulation in dolphins (Stenella coeruleoalba) from French Atlantic and Mediterranean coasts. Sci Tot Environ 1991;104:191-209.

Bacci E. Mercury in the Mediterranean. Mar Pollut Bull 1989;20:59-63.

Beck KM, Fair P, McFee W, Wolf D. Heavy metals in livers of bottlenose dolphins stranded along the South Carolina coast. Mar Pollut Bull 1997;34:734-739.

Berrow SD, Mchugh B, Glynn D, McGovern E, Parsons KM, et al. Organochlorine concentrations in resident bottlenose dolphins (Tursiops truncatus) in the Shannon estuary, Ireland. Mar Pollut Bull 2002; 44:1296-1313. 
Bloom NS. On the chemical form of mercury in edible fish and marine invertebrate tissue. Can J Fish Aquat Sci 1992;49:1010-1016.

Borrell A, Cantos G, Pastor T, Aguilar A. Organochlorine compounds in common dolphin (Delphinus delphis) from the Atlantic and Mediterranean waters of Spain. Environ Pollut 2001;114:265-274.

Borrell A, Aguilar A, Tornero V, Sequeira M, Fernandez G, et al. Organochlorine compounds and stable isotopes indicate bottlenose dolphin subpopulation structure around the Iberian Peninsula. Environ Internat 2006;32:516-523.

Boyle EA. Cadmium: Chemical tracer of deep water paleoceanography. Paleoceanography $1988 ; 3: 471-489$.

Boyle EA, Sclater F, Edmond JM. On the marine geochemistry of cadmium. Nature 1976;263:42-44.

Bryan CE, Christopher SJ, Balmer BC, Wells RS. Establishing baseline levels of trace elements in blood and skin of bottlenose dolphins in Sarasota Bay, Florida: Implications for non-invasive monitoring. Sci Tot Environ 2007;388:325-342.

Bustamante P, Caurant F, Fowler SW, Miramand P. Cephalopods as a vector for the transfer of cadmium to top marine predators in the north-east Atlantic Ocean. Sci Environ 1998;220:71-80.

Bustamante P, Garrigue C, Breau L, Caurant F, Dabin W, Greaves J, Dodemont R. Trace elements in two odontocete species (Kogia breviceps and Globicephala macrorhynchus) stranded in New Caledonia (South Pacific). Environ Pollut 2003;124:263-271.

Bustamante P, Morales CF, Mikkelsen B, Dam M, Caurant F. Trace element bioaccumulation in grey seals Halichoerus grypus from the Faroe Islands. Mar Ecol Progr Ser 2004;267:291301.

Bustamante P, Lahaye V, Durnez C, Churlaud C, Caurant F. Total and organic Hg concentrations in cephalopods from the North Eastern Atlantic waters: Influence of geographical origin and feeding ecology. Sci Tot Environ 2006;368:585-596.

Canella EJ, Kitchener DJ. Differences in mercury levels in female sperm whale, Physeter macrocephalus (Cetacea: Odontoceti). Aust Mamm 1992;15:121-123.

Carvalho ML, Pereira RA, Brito J. Heavy metals in soft tissues of Tursiops truncatus and Delphinus delphis from west Atlantic Ocean by X-ray spectrometry. Sci Tot Environ 2002;292:247-254. 
Caurant F, Amiard JC, Amiard-Triquet C, Sauriau PG. Ecological and biological factors controlling the concentrations of trace elements (As, $\mathrm{Cd}, \mathrm{Cu}, \mathrm{Hg}, \mathrm{Se}, \mathrm{Zn}$ ) in delphinids Globicephala melas from the North Atlantic Ocean. Mar Ecol Progr Ser 1994;103:207-219.

Caurant F, Amiard-Triquet C. Cadmium contamination in pilot whales Globicephala melas: Source and potential hazard to the species. Mar Pollut Bull 1995;30:207-210.

Caurant F, Navarro M, Amiard JC, Mercury in Pilot Whales: possible limits to the detoxification process. Sci Tot Environ 1996;186:95-104.

Cardellicchio N. Persistent contaminants in dolphins: an indication of chemical pollution in the Mediterranean Sea. Water Sci Tech 1995;32(9-10):331-340.

Cardellicchio N, Decataldo A, Di Leo A, Misino A. Accumulation and tissue distribution of mercury and selenium in striped dolphins (Stenella coeruleoalba) from the Mediterranean Sea (Southern Italy). Environ Pollut 2002;116:265-271.

Carro N, Garcia I, Ignacio M, Mouteira A. Levels and distribution patterns of Polychlorinated biphenyl congeners in surface sediments from Galicia coast (Northwestern, Spain) according to granulometric characteristics. Environ Tech 2002;23:919-930.

Chappuis P. Les Oligoéléments en médecine et biologie, Lavoisier editor, Paris; 1991.

Chouvelon T, Spitz J, Caurant F, Méndez-Fernandez P, Autier J, et al. Enhanced bioaccumulation of mercury in deep-sea fauna from the Bay of Biscay (north-east Atlantic) in relation to trophic positions identified by analysis of carbon and nitrogen stable isotopes. Deep-Sea Res I 2012;65:113-124.

Christopher SJ, Pugh RS, Ellisor MB, Mackey EA, Spatz RO, et al. Description and results of the NIST/NOAA 2005 interlaboratory comparison exercise for trace elements in marine mammals. Accred Qual Assur 2007;12:175-187.

Ciesielski T, Szefer P, Bertenyi Z, Kuklik I, Skóra K, et al. Interspecific distribution and coassociations of chemical elements in the liver tissue of marine mammals from the Polish Economical Exclusive Zone, Baltic Sea. Environ Inter 2006;32:524-532.

Cuvin-Aralar A, Furness RW. Mercury and selenium interaction: A Review. Ecotoxical Environ Safety 1991;21:283-294.

Das K, Debacker V, Bouquegneau JM. Metallothioneins in marine mammals. Cell Mol Biol 2000a;46:283-294.

Das K, Lepoint G, Loizeau V, Debacker V, Dauby P, et al. Tuna and dolphin associations in the North-east Atlantic: Evidence of diferent ecological niches from stable isotope and heavy metal measurements. Mar Pollut Bull 2000b;40:102-109. 
Das K, Debacker V, Pillet S, Bouquegneau JM. Heavy metals in marine mammals. In: Vos JG, Bossart GD, Fournier M, O’shea TJ, editors. Toxicology of Marine Mammals Volume 3 Systems. Taylor \& Francis Inc, New York; 2003a. p. 135-167.

Das K, Beans C, Holsbeek L, Mauger G, Berrow SD, et al. Marine mammals from northeast atlantic: relationship between their trophic status as determined by $\mathrm{d} 13 \mathrm{C}$ and $\mathrm{d} 15 \mathrm{~N}$ measurements and their trace metal concentrations. Mar Environ Res 2003b;56:349-365

Das K, Siebert U, Fontaine M, Jauniaux T, Holsbeek L, Bouquegneau JM. Ecological and pathological factors related to trace metal concentrations in harbour porpoises Phocoena phocoena from the North Sea and adjacent areas. Mar Ecol Progr Ser 2004a;281:283-295.

Das K, Holsbeek L, Browning J, Siebert U, Birkun Jr A, Bouquegneau JM. Trace metal and stable isotope measurements $\left(\delta^{13} \mathrm{C}\right.$ and $\left.\delta^{15} \mathrm{~N}\right)$ in the harbour porpoise Phocoena phocoena relicta from the Black Sea. Environ Pollut 2004b;131:197-204.

Decataldo A, Di Leo A, Giandomenico S, Cardellicchio N. Association of metals (mercury, cadmium and zinc) with metallothionein-like proteins in storage organs of stranded dolphins from the Mediterranean sea (Southern Italy). J Environ Monit 2004;6:361-367.

Dietz R, Norgaard J, Hansen JC. Have Artic marine mammals adapted to high cadmium levels? Mar Pollut Bull 1998;36:490-492.

Dietz R, Riget FF, Born EW. An assessment of selenium to mercury in Greenland marine animals. Sci Tot Environ 2000;245:15-24.

Dietz R, Sonne C, Basu N, Braune B, O'Hara T, et al. What are the toxicological effects of mercury in Arctic biota? Sci Tot Environ 2013;443:775-790.

Elinder CG, Järup L. Cd exposure and health risks: recent findings. Ambio 1996;25:370-373.

Engle DW, Brouwer M. Metallothionein and metallothionein-like proteins: physiological importance. Adv Comp Environ Physiol 1989;5:54-75.

Falconer CR, Davies IM, Topping G. Trace metals in the common porpoise, Phocoena phocoena. Mar Environ Res 1983;8:119-127.

Fernández de la Cigoña E. Os cabaleiros do mar: baleas e golfiños das nosas augas. Guía dos cetáceos de Galicia e Iberia. Ser. Natureza Galega - Tomo III. Asociación Galega para a Cultura e a Ecoloxía (AGCE), Vigo; 1990.

Figueiras FG, Labarta U, Fernández-Reiriz JM. Coastal upwelling, primary production and mussel growth in the Rias Baixas of Galicia. Hydrobiologia 2002;484:121-131.

Frodello JP, Roméo M, Viale D. Distribution of mercury in the organs and tissues of five toothed-whale species of the Mediterranean. Environ Pollut 2000;108:447-452. 
FrodelloJP, Marchand B. Cadmium, copper, lead and zinc in five toothed whales species of the Mediterranean Sea. Int J Toxicol 2001;20:339-343.

Fujise Y, Honda K, Tatsukawa R, Mishima S.Tissue Distribution of Heavy Metals in Dali's Porpoise in the Northwestern Pacific. Mar Pollut Bull 1988;19:226-230.

Gaskin DE, Smith GJD, Arnold PW, Louisy MV, Franck R, Holdrinet M, McWade JW. Mercury, DDT, dieldrin, and PCB in two species of Odontoceti (Cetacea) from St Lucia, Lesser Antilles. J Fish Res Board Can 1974;31(7):1235-1239.

Gaskin DE, Stonefield KI, Suda P, Frank R. Changes in mercury levels in harbor porpoises from the Bay of Fundy, Canada, and adjacent waters during 1969-1977. Arch Environ Contam Toxicol 1979;8:733-762.

George SG, Olsson PE. Metallothioneins as indicators of trace metal pollution. In: Kramer K JM, editor. Biomonitoring of coastal waters estuaries. Boca Raton: CRC Press; 1994.

Gochfeld M. Factors influencing susceptibility to metals. Environ Health Persp 1997;105:817-822.

Griesel S, Kakuschke A, Siebert U, Prange A. Trace element concentrations in blood of harbor seals (Phoca vitulina) from the Wadden Sea. Sci Tot environm 2008;392: 313323.

Guerra A. Mollusca, Cephalopoda. Fauna Ibérica, vol. 1. Museo Nacional de Ciencias Naturales (CSIC), Madrid; 1992.

Hohn AA, Lockyer C. Protocol for obtaining age estimates from harbour porpoise teeth. Appendix 3, Report of the harbour porpoise age determination workshop. In: Bjørge A, Donovan GP, editors. Biology of phocoenids. Rep Int Whal Commn, Cambridge; 1995.

Holsbeek L, Siebert U, Joiris CR. Heavy metals in dolphins stranded on the French Atlantic coast. Sci Tot Environ 1998;217:241-249.

Honda K, Tatsukawa R, Fujiyama T. Distribution characteristics of heavy metals in the organs and tissues of striped dolphin Stenella coeruleoalaba. Agric Biol Chem 1982; 46(12):3011-21.

Honda K, Tatsukawa R, Itano K, Miyasaki N, Fujiyama T. Heavy metal concentrations in muscle, liver and kidney tissue of striped dolphin, Stenella coeruleoalba, and their variations with body length, weight, age and sex. Agric Biol Chem 1983;47:1219-1228.

Honda K, Yamamoto Y, Kato H, Tatsukawa R. Heavy metal accumulation and their recent changes in Southern minke whales Balaenoptera acutorostrata. Arch Environ Contam Toxicol 1987;16: 209-216. 
Itano K, Kawai Si, Miyazaki N, Tatsukawa R, Fujiyama T. Mercury and selenium levels in striped dolphins caught off the Pacific coast of Japan. Agric Biol Chem 1984;48:1109-1116. Julshman K, Andersen A, Ringdall O, Morkore J. Trace elements intake in the Faroe Islands I. Element levels in edible parts of Pilot whales (Globicephala meleanus). Sci Tot Environ 1987;65:53-62.

Junoy J, Castellanos C, Viéitez JM, de la Huz MR, Lastra M. The macroinfauna of the Galician sandy beaches (NW Spain) affected by the Prestige oil-spill. Mar Pollut Bull 2005;50:526-536.

Kemper C, Gibbs P, Obendorf D, Marvanek S, Lenghaus C. A review of heavy metal and organochlorine levels in marine mammals in Australia. Sci Tot Environ 1994;154:129-139.

Koeman JH, Peeters VHM, Koudstaal-Hol CHM, Tijoe PS, De Goeu JJM. Mercury selenium correlation in marine mammals. Nature 1973;246:385-386.

Koeman JH, van de Ven WSM, Goeij JJM, Tjioe PS, vanHaaften JL. Mercury and selenium in marine mammals and birds. Sci Total Environ 1975;3:279-287.

Kubota R, Kunito T, Tanabe S. Arsenic accumulation in the liver tissue of marine mammals, Environ. Pollut 2001;115:303-312.

Kuehl DW, Haebler R, Potter C. Coplanar PCB and metal residues in dolphins from the U.S. Atlantic coast including Atlantic bottlenose obtained during the 1987/88 mass mortality. Chemosphere 1994;28:1245-1253.

Kuiken T, Garcia Hartmann M. Proceedings of the first European Cetacean Society workshop on 'Cetacean pathology: dissection techniques and tissue sampling'. ECS Newslett $1991 ; 17: 1-39$.

Kunito T, Nakamura S, Ikemoto T, Anan Y, Kubota R, et al. Concentration and subcellular distribution of trace elements in liver of small cetaceans incidentally caught along the Brazilian coast. Mar Pollut Bull 2004;49:574-587.

Lahaye V, Bustamante P, Spitz J, Dabin W, Das K, Pierce GJ, Caurant F. Long-term dietary segregation of common dolphins Delphinus delphis in the Bay of Biscay, determined using cadmium as an ecological tracer. Mar Ecol Progr Ser 2005;305:275-285.

Lahaye V, Bustamante P, Dabin W, Van Canneyt O, Dhermain F, Cesarini C, Pierce GJ, Caurant F. New insights from age determination on toxic element accumulation in striped and bottlenose dolphins from Atlantic and Mediterranean waters. Mar Pollut Bull 2006;52:12191230.

Lahaye V, Bustamante P, Law RJ, Learmonth JA, Santos MB, Boon JP, Rogan E, Dabin W, Addink MJ, López A, Zuur AF, Pierce GJ, Caurant F. Biological and ecological 
factors related to trace element levels in harbour porpoises (Phocoena phocoena) from European waters. Mar Environ Res 2007;64:247-266.

Lavery TJ, Butterfield N, Kemper C, Reid RJ. Sanderson K Metals and selenium in the liver and bone of three dolphin species from South Australia, 1988-2004. Sci Tot Environ 2008;390:77-85.

Law RJ, Fileman CE, Hopkins AD, Baker JR, Harwood J, et al. Concentrations of trace metals in the livers of marine mammals (Seals, Porpoises and Dolphins) from waters around the British Isles. Mar Pollut Bull 1991;22:183-191.

Law RJ, Jones BR, Baker JR, Kennedy S, Milne R, Morris RJ. Trace metals in the livers of marine mammals from the Welsh coast and the Irish Sea. Mar Pollut Bull 1992;24:296-304.

Law RJ. Metals in marine mammals. In: Beyer WN, Heinz, GH Redmond-Norwood AW, editors. Environmental Contaminants in Wildlife: Interpreting Tissue Concentrations. CRC Press, US; 1996.

Law RJ, Bennett ME, Blake SJ, Allchin CR, Jones BR, Spurrier CJH. Metals and organochlorines in pelagic cetaceans stranded on the coasts of England and Wales. Mar Poll Bull 2001;42(6):522-526.

Lemos LS, de Moura JF, Hauser-Davis RA, de Campos RC, Siciliano S. Small cetaceans found stranded or accidentally captured in southeastern Brazil: Bioindicators of essential and non-essential trace elements in the environment. Ecotoxicol Environ Saf 2013;97: 166-175.

Lockyer C. A report on patterns of deposition of dentine and cement in teeth of pilot whales, genus Globicephala. Rep Inter Whal Comm Spec Issue 1993;14:138-161.

López A, Santos MB, Pierce GJ, Gonzalez AF, Valeiras X, Guerra A. Trends in strandings of cetaceans on the Galician coast, NW Spain, during the 1990s. Mar Biol Assoc UK 2002;82:3916/1-9.

López A, Pierce GJ, Santos MB, Gracia J, Guerra A. Fishery by-catches of marine mammals in Galician waters: results from on-board observations and an interview survey of fishermen. Conserv Biol 2003;111:25-40.

López A, Pierce GJ, Valeiras X, Santos MB, Guerra A. Distribution patterns of small cetaceans in Galician waters. J Mar Biol Assoc UK 2004;84:1-13.

Mackey EA, Demiralp R, Becker PR, Greenberg RR, Koster BJ, et al. Trace element concentrations in cetacean liver tissues archived in the National Marine Mammal Tissue Bank. Sci Tot Environ 1995;175:25-41. 
Marcovecchio JE, Moreno VJ, Bastida RO, Gerpe MS, Rodriguez DH. Tissue distribution of heavy metals in small cetaceans from the Southwestern Atlantic Ocean. Mar Pollut Bull 1990;21:299-304.

Maher W, Butler E. Arsenic in the marine environment. Appl Organomet Chem 1988;2:191214.

Martoja R, Berry JP. Identification of tiemannite as a probable product of demethylation of mercury by selenium in cetaceans. A complement to the scheme of the biological cycle of mercury. Vie Milieu 1980;30:7-10.

MacDonald CR, Sprague JB. Cadmium in marine invertebrates and arctic cod in the Canadian Arctic. distribution and ecological implications. Mar Ecol Progr Ser 1988;47:17-30.

Méndez-Fernandez P, Webster L, Chouvelon T, Bustamante P, Ferreira M, González AF, et al. An assessment of contaminant concentrations in toothed whale species of the NW Iberian Peninsula: Part I. Persistent organic pollutants. Sic Tot Environ submitted.

Méndez-Fernandez P, Pierce GJ, Bustamante P, Chouvelon T, Ferreira M, González A. F, et al. Ecological niche segregation among five toothed whale species off the NW Iberian Peninsula using ecological tracers as multi-approach. Mar Biol 2013;1-16.

Monaci F, Borrel A, Leonzio C, Marsili L, Calzada N. Trace elements in striped dolphins (Stenella coeruleoalba) from the western Mediterranean. Environ Pollut 1998;99:61-68.

Moreno R, Jover L, Diez C, Sanpera C. Seabird feathers as monitors of the levels and persistence of heavy metal pollution after the Prestige oil spill. Environ Pollut 2011;159:2454-2460.

Morris RJ, Law RJ, Allchin CR, Kelly CA, Fileman CF. Metals and organochlorines in dolphins and porpoises of Cardigan Bay, West Wales. Mar Pollut Bull 1989;20:512-523.

Monteiro LR, Costa V, Furness RW, Santos RS. Mercury concentrations in prey fish indicate enhanced bioaccumulation in mesopelagic environments. Mar Ecol Progr Ser 1996;141:2125 .

Muir DCG, Wagemann R, Grift NR, Norstrom RJ, Simon M, et al. Organochlorine chemical and heavy metal contaminants in White-beaked dolphins (Lagenorhynchus albirostris) and pilot whales (Globicephala melaena) from the coast of Newfoundland, Canada. Arch Environ Contam Toxicol 1988;17:613-629.

Murphy S, Pierce DGJ, Law RJ, Bersuder P, Jepson PD, et al. Assessing the Effect of Persistent Organic Pollutants on Reproductive Activity in Common Dolphins and Harbour Porpoises. J Northwest Atl Fish Sci 2010;42:153-173. 
Neff JM. Ecotoxicology of arsenic in the marine environment. Environ Toxicol Chem 1997;16(5):917-927

Nyman M, Koistinen J, Fant ML, Vartiainen T, Helle E. Current levels of DDT, PCB and trace elements in the Baltic ringed seals (Phoca hispida baltica) and grey seals (Halichoerus grypus). Environ Pollut 2002;119:399-412.

O'Shea T. Environmental contaminants and marine mammals. In: Reynolds III JE, Rommel SA, editors. Biology of Marine Mammals. Smithsonian Institution Press, USA; 1999.

Paludan-Müller P, Agger CT, Dietz R, Kinze CC. Mercury, cadmium, zinc, copper and selenium in harbour porpoise (Phocoena phocoena) from West Greenland. Polar Biol $1993 ; 13: 311-320$.

Pelletier E. Mercury-selenium interactions in aquatic organism: a review. Mar Environ Res 1985;18:111-132.

Penas-Patiño XM, Piñeiro-Seage A. Cetáceos, focas e tartarugas das costas ibéricas. Consellería de Pesca, (Xunta de Galicia), Santiago de Compostela; 1989.

Pérez-Lòpez M, Cid F, Oropesa AL, Fidalgo LE, Beceiro AL, Soler F. Heavy metal and arsenic content in seabirds affected by the Prestige oil spill on the Galician coast (NW Spain). Sci Tot Environ 2006;359:209-220.

Pierce GJ, Santos MB, Murphy S, Learmonth JA, Zuur AF, Rogan E, et al. Bioaccumulation of persistent organic pollutants in female common dolphins (Delphinus delphis) and harbour porpoises (Phocoena phocoena) from western European seas: Geographical trends, causal factors and effects on reproduction and mortality. Environ Pollut 2008; 153:401-415.

Pierce DGJ, Caldas M, Cedeira J, Santos MB, Llavona A, et al. Trends in cetacean sightings along the Galician coast, north-west Spain, 2003-2007, and inferences about cetacean habitat preferences. J Mar Biol Assoc UK 2010;90:1547-1560.

Pompe-Gotal J, Srebocan E, Gomercic H, Prevendar Crnic A. Mercury concentrations in the tissues of bottlenose dolphins (Tursiops truncatus) and striped dolphins (Stenella coeruloalba) stranded on the Croatian Adriatic coast. Veterinarni Medicina 2009; 54:598604.

Prego R, Cobelo-Garcia A. Twentieth century overview of heavy metals in the Galician Ria (NW Iberian Peninsula). Environ Pollut 2003;121:425-452.

Prego R, Cobelo-Garcìa A. Cadmium, copper and lead contamination of the seawater column on the Prestige shipwreck (NE Atlantic Ocean). Anal Chim Acta 2004;524:2326. 
R Development Core Team. R: a language and environment for statistical computing. $\mathrm{R}$ Foundation for Statistical Computing, Vienna, www.R-project.org; 2010.

Rawson AJ, Patton GW, Hofmann S, Pietra GG. Liver abnormalities associated with chronic mercury accumulation in stranded Atlantic bottlenose dolphins. Ecotoxicol Environ Safety 1993;25: 41-47.

Ringelstein J, Pusineri C, Hassani S, Meynier L, Nicolas R, Ridoux V. Food and feeding ecology of the striped dolphin, Stenella coeruleoalba, in the oceanic waters of the north-east Atlantic. Journal of the Marine Biological Association of the United Kingdom 2006;86:909918.

Roditi-Elasar M, Kerem D, Hornung H, Kress N, Shoham-Frider E, et al. Heavy metal levels in bottlenose and striped dolphins off the Mediterranean coast of Israel. Mar Pollut Bull 2003;46:503-512.

Rogan E, Murphy S, Learmonth JA, Gonzalez A, Dabin W. Age determination in small cetaceans from the NE Atlantic. Appendix 4. In: Pierce GJ, Santos MB, Learmonth JA, Smeenk, C and others editors. Bioaccumulation of persistent organic pollutants in small cetaceans in European waters: transport pathways and impact on reproduction. Final Report to the European Commission's Directorate General for Research on Project EVK3-2000-00027, Aberdeen; 2004.

Romero R, Guitian J, Ruiz-Olmo J. Changes in the diet of coastal otters after the Prestige oil spill (Galicia, north-west Spain). J Zool 2012;286:22-29.

Ruelas JR, Páez-Osuna F. Distribution of cadmium, copper, iron, manganese, lead, and zinc in Spinner Dolphins Stenella longirostris ztranded in La Paz lagoon, Southwest Gulf of California. Bull Environ Contam Toxicol 2002;69:408-414.

Santos MB, Pierce GJ. The Diet of Harbour porpoise (Phocoena phocoena) in the Northeast Atlantic. Oceanogr Mar Biol: An annual review 2003;41:355-390.

Santos MB, Pierce GJ, López A, Martínez JA, Fernández MT, et al. Variability in the diet of common dolphins (Delphinus delphis) in Galician waters 1991-2003 and relationship with prey abundance. ICES CM. 2004

Santos MB, Fernandez R, Lopez A, Martinez JA, Pierce GJ. Variability in the diet of bottlenose dolphin, Tursiops truncatus, in Galician waters, north-western Spain, 1990-2005. J Mar Biol Assoc UK 2007;87:231-241. 
Santos MB, Monteiro SS, Vingada JV, Ferreira M, López A, et al. Patterns and trends in the diet of long-finned pilot whales (Globicephala melas) in the Northeast Atlantic. Mar Mam Sci 2013a; doi: 10.1111/mms.12015

Santos MB, Saavedra C, Pierce GJ. Quantifying the predation on sardine and hake by cetaceans in the Atlantic waters of the Iberian Peninsula. Deep Sea Res II 2013b; doi: 10.1016/j.dsr2.2013.09.040.

Sonne C, Dam M, Leifsson PS, Dietz R. Liver and renal histopathology of North Atlantic long-finned pilot whales (Globicephala melas) contaminated with heavy metals and organochlorine compounds. Toxicol Environ Chem 2010;92:969-985.

Spitz J, Richard E, Meynier L, Pusineri C, Ridoux V. Dietary plasticity of the oceanic striped dolphin, Stenella coeruleoalba, in the neritic waters of the Bay of Biscay. J Sea Res 2006;55:309-320.

Spitz J, Cherel Y, Bertin S, Kiszka J, Dewez A, Ridoux V. Prey preferences among the community of deep-diving odontocetes from the Bay of Biscay, Northeast Atlantic. Deep-Sea Res Pt I 2011;58:273-282.

Stavros H-CW, Bonde RK, Fair PA. Concentrations of trace elements in blood and skin of Florida manatees (Trichechus manatus latirostris). Baseline/Mar Pollut Bull 2008;56:1215-1233.

Stockin KA, Law RJ, Duignan PJ, Jones GW, Porter L, et al. Trace elements, PCBs and organochlorine pesticides in New Zealand common dolphins (Delphinus sp.). Sci Tot Environ 2007;387:333-345.

Stoneburner DL. Heavy metals in tissues of stranded short-finned pilot whales. Sci Tot Environ 1978;9:293-297.

Storelli MM, Marcotrigiano GO. Subcellular distribution of heavy metals in livers and kidneys of Stenella coeruleoalba and Tursiops truncatus from the Mediterranean Sea. Baseline/Mar Pollutn Bull 2002;44:71-81.

Strand J, Larsen MM, Lockyer C. Accumulation of organotin compounds and mercury in harbour porpoises (Phocoena phocoena) from the Danish waters and West Greenland. Sci Tot Environ 2005;350:59-71.

Szefer P, Zdrojewska I, Jensen J, Lockyer C, Skora K, et al. Intercomparison Studies on Distribution and Coassociations of Heavy Metals in Liver, Kidney, and Muscle of Harbor Porpoise, Phocoena phocoena, from Southern Baltic Sea and Coastal Waters of Denmark and Greenland. Archives Environ Contam Toxicol 2002;42:508-522. 
Teigen S, Andersen R, Daae HL, Skaare JU. Heavy metal content in liver and kidneys of grey seals (Halichoerus grypus) in various life stages correlated with metallothioneins levels: some metal-binding characteristics of this protein. Environ Toxicol Chem 1999;18:2364-2369.

Tilbury KL, Stein JE, Meador JP, Krone CA, Chan SL. Chemical contaminants in harbor porpoise (Phocoena phocoena) from the North Atlantic coast: Tissue concentrations and intra- and inter-organ distribution. Chemosphere 1997;34:2159-2181.

Troisi GM, Haraguchi K, Simmonds MP, Mason CF. Methyl sulphone metabolites of polychlorinated biphenyls (PCBS) in cetaceans from the Irish and the Aegean Seas. Archives Environ Contam Toxicol 1998;35:121-128.

Thompson DR. Heavy metals in marine vertebrates. In: Furness RW, Rainbow PS, editors. Heavy metals in the marine environment. CRC Press, Boca Raton, 1990. p. 143-182.

Thompson DR, Furness RW, Monteiro LR. Seabirds as biomonitors of mercury inputs to epipelagic and mesopelagic marine food chains. Sci Tot Environ 1998;213:299-305.

Underwood EJ. Trace elements in human and animal nutrition. Academic Press, New York; 1977.

Wagemann R, Snow NB, Lutz A, Scott DP. Heavy metals in tissues and organs of the narwhal (Monodon monoceros). Can J Fish Aquat Sci 1983;40:206-214.

Wagemann R, Stewart REA, Lockhart WL, Stewart BE, Povoledo M. Trace metals and methyl mercury: associations and transfer in harp seal (Phoca groenlandica) mothers and their pups. Mar Mam Sci 1988;4:339-355.

Wagemann R, Lockhart LW, Welch H, Innes S. Arctic marine mammals as integrators and indicators of mercury in the Arctic. Water Air Soil Pollut 1995;80:683-693.

Wells DE, Campbell LA, Ross HM, Thompson PM, Lockyer CH. Organochlorine residues in harbour porpoise and bottlenose dolphins stranded on the coast of Scotland, 1988-1991. Sci TotEnviron 1994;151:77-99.

Zegers BN, Mets A, Van Bommel R, Minkenberg C, Hamers T, et alLevels of hexabromocyclododecane in harbor porpoises and common dolphins from western European seas, with evidence for stereoisomer-specific biotransformation by cytochrome P450. Environ Sci Tech 2005;39:2095-2100.

Zhou JL, Salvador SM, Liu YP, Sequeira M. Heavy metals in the tissues of common dolphins Delphinus delphis stranded on the Portuguese coast. Sci Tot Environ 2001;273:61-76. 


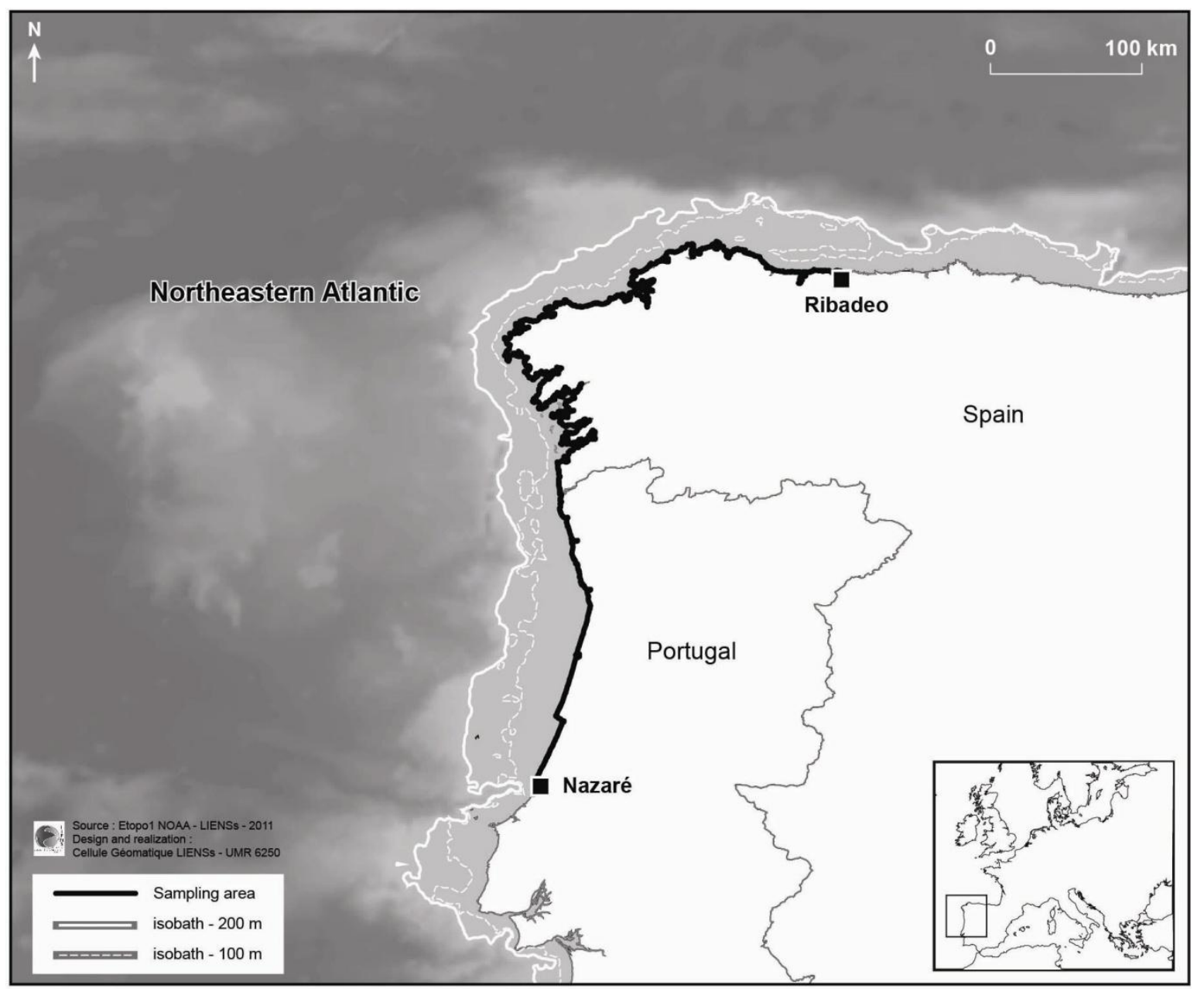

Fig 1. Map of the study area including the 100 and $200 \mathrm{~m}$ isobaths. The $200 \mathrm{~m}$ isobath was taken as the limit for the shelf-break. The black line contouring the coast represents the length of the coastline which constituted the sampling zone. 


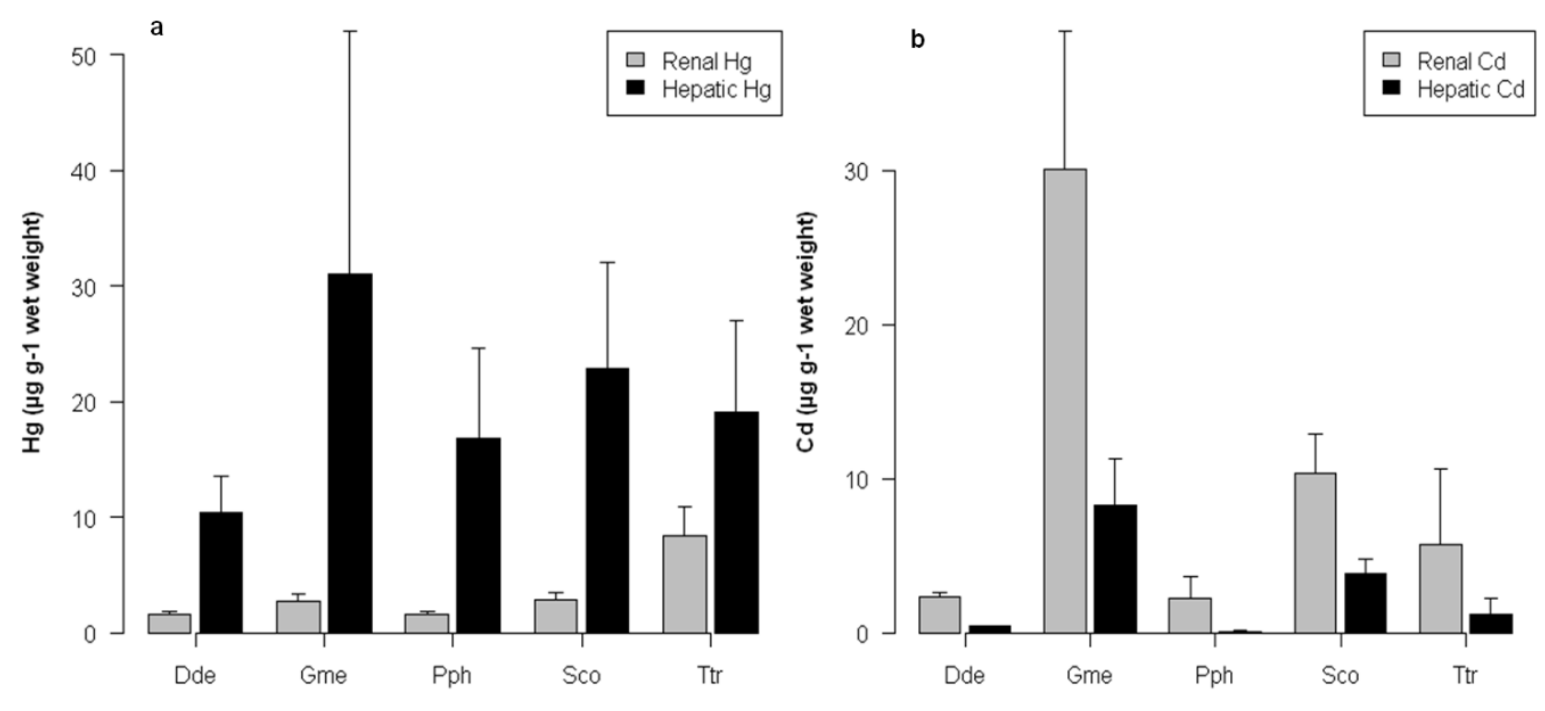

Fig 2. Concentrations (mean $\pm \mathrm{SE}$, standard error, in $\mu \mathrm{g} \mathrm{g}^{-1}$ wet weight) of mercury (a) and cadmium (b) in the liver and kidney of Dde: common dolphin (Delphinus delphis), Gme: pilot whale (Globicephala melas), Pph: harbour porpoise (Phocoena phocoena), Sco: striped dolphin (Stenella coeruleoalba) and Ttr: bottlenose dolphin (Tursiops truncatus) from the North West Iberian Peninsula. Mercury $(\mathrm{Hg})$ and cadmium $(\mathrm{Cd})$ were chosen since each of them represented one of the two patterns of tissue distribution of the 14 trace elements analysed. 


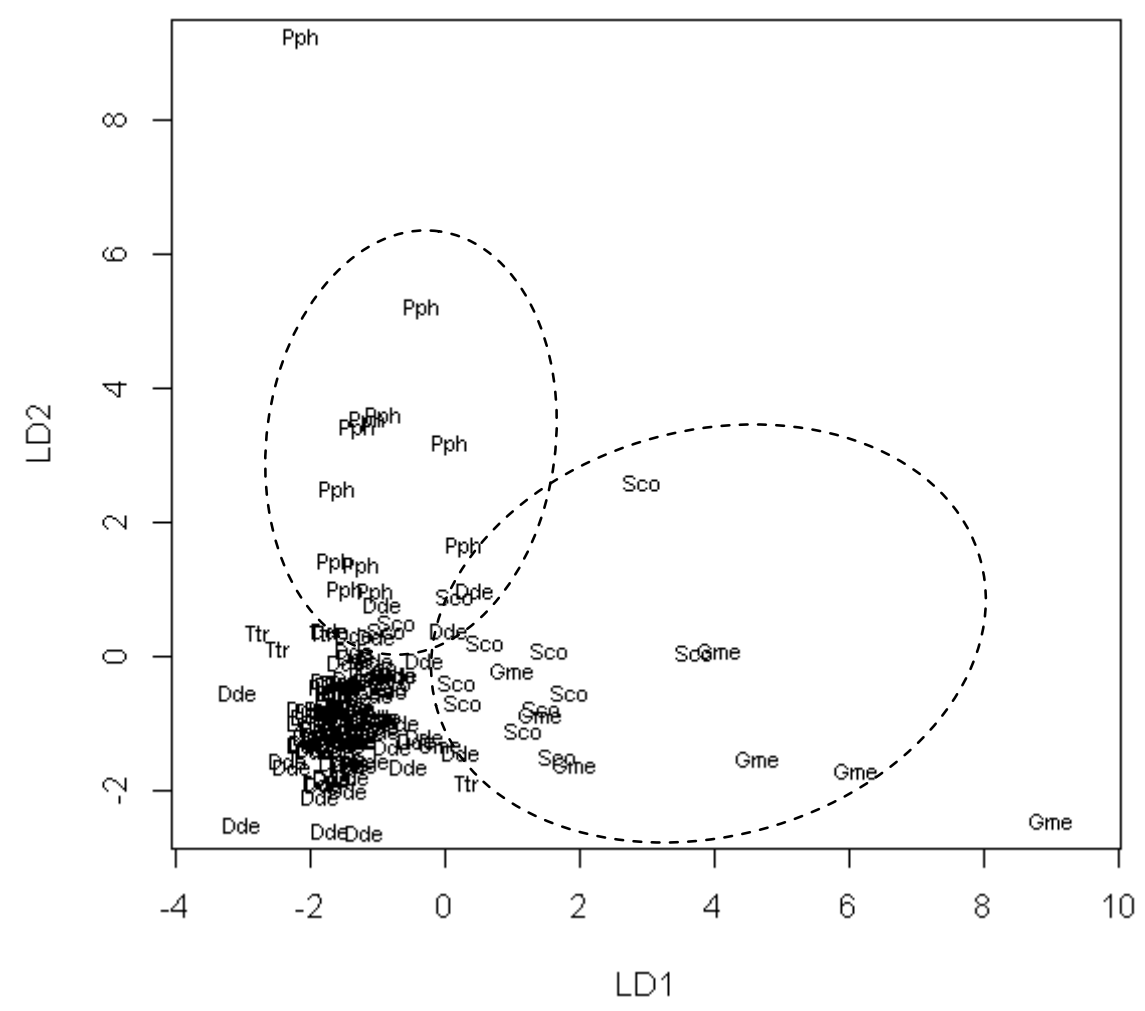

Fig 3. Results of discriminant analysis (DA) on trace element concentrations analysed in liver and kidney (data where the concentrations were < LoD are not shown; see Table 1) for Dde: common dolphin (Delphinus delphis), Gme: pilot whale (Globicephala melas), Pph: harbour porpoise (Phocoena phocoena), Sco: striped dolphin (Stenella coeruleoalba) and Ttr: bottlenose dolphin (Tursiops truncatus) from the North West Iberian Peninsula: bi-plot for axes 1-2 (i.e. LD1 and LD2). 


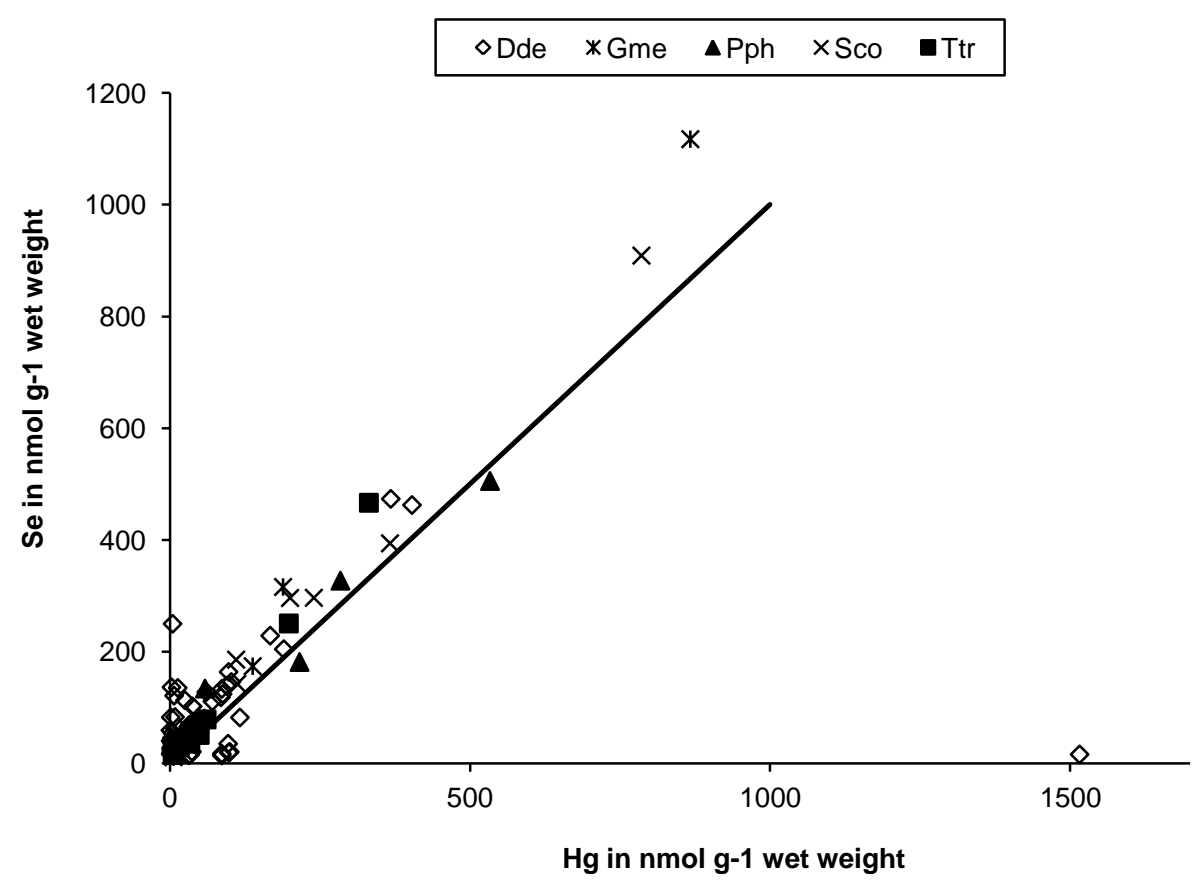

Fig 4. Molar Se and molar $\mathrm{Hg}$ concentrations (nmol g ${ }^{-1}$ wet weight) in liver tissue of Dde: common dolphin (Delphinus delphis), Gme: pilot whale (Globicephala melas), Pph: harbour porpoise (Phocoena phocoena), Sco: striped dolphin (Stenella coeruleoalba) and Ttr: bottlenose dolphin (Tursiops truncatus) from the North West Iberian Peninsula. The solid line indicate the $\mathrm{Hg}$ :Se molar ratio of 1 . 
Table 1. Trace element concentrations (mean $\pm \mathrm{SD}, \mu \mathrm{g} \mathrm{g}^{-1}$ wet weight) in kidney and liver of common dolphin (Delphinus delphis), pilot whale (Globicephala melas), harbour porpoise (Phocoena phocoena), striped dolphin (Stenella coeruleoalba) and bottlenose dolphin (Tursiops truncatus) from the North West Iberian Peninsula. The total number of samples ' $n$ ' analysed per species is indicated, with the values of kidney samples on the left side and those of liver samples on the right side. Age values are expressed as years (mean \pm SD).

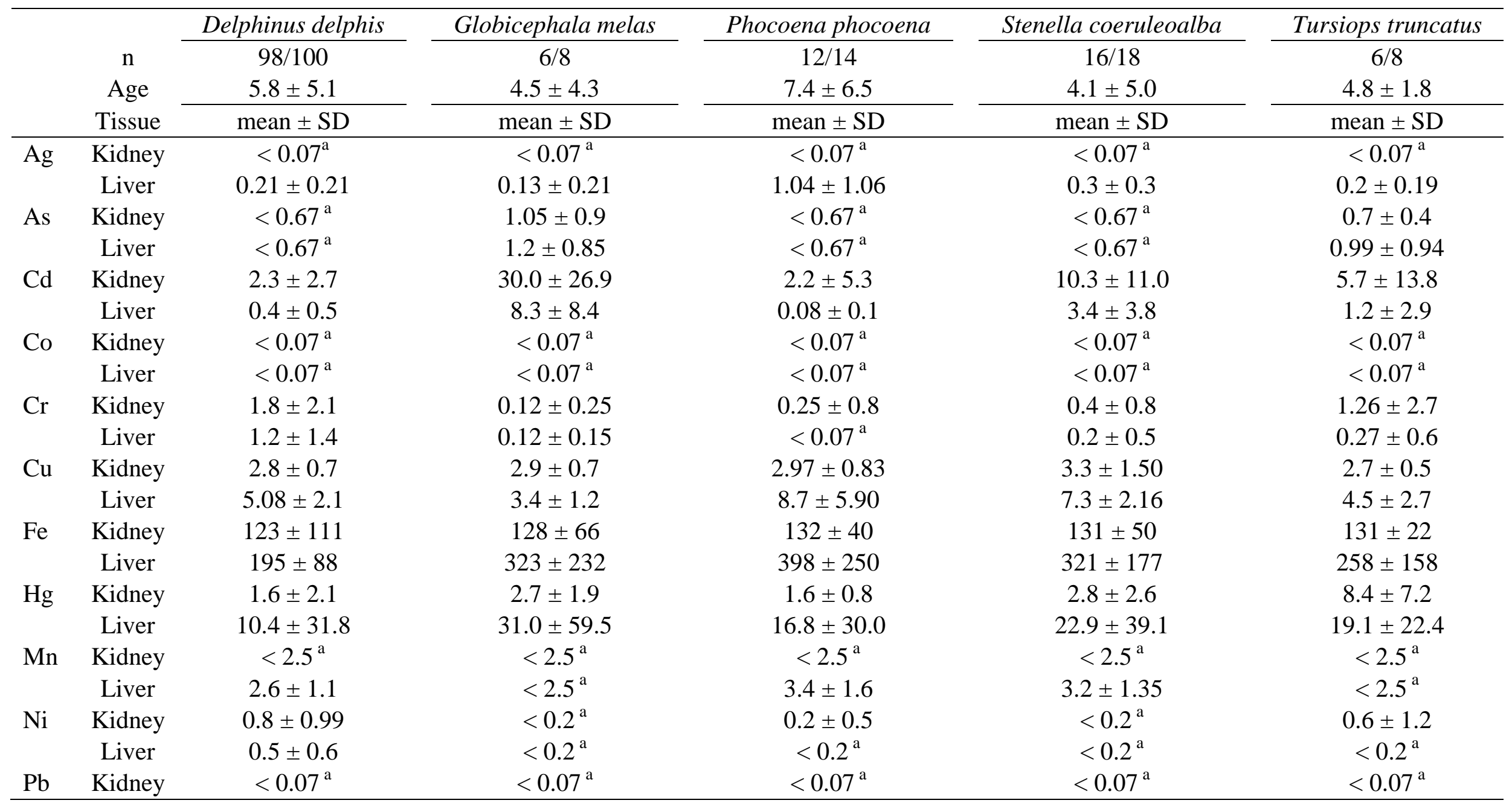


Table 1. (Continued)

\begin{tabular}{|c|c|c|c|c|c|c|}
\hline & Liver & $<0.07^{\mathrm{a}}$ & $<0.07^{\mathrm{a}}$ & $<0.07^{\mathrm{a}}$ & $<0.07^{\mathrm{a}}$ & $<0.07^{\mathrm{a}}$ \\
\hline \multirow[t]{2}{*}{$\mathrm{Se}$} & Kidney & $2.7 \pm 1.1$ & $2.9 \pm 1.6$ & $3.0 \pm 0.95$ & $3.2 \pm 1.4$ & $4.6 \pm 3.1$ \\
\hline & Liver & $5.0 \pm 5.8$ & $16.9 \pm 30.1$ & $8.0 \pm 11.6$ & $12.3 \pm 17.2$ & $10.8 \pm 13.0$ \\
\hline V & Kidney & $<1^{\mathrm{a}}$ & $<1^{\mathrm{a}}$ & $<1^{\mathrm{a}}$ & $<1^{\mathrm{a}}$ & $<1^{\mathrm{a}}$ \\
\hline \multirow[t]{2}{*}{$\mathrm{Zn}$} & Kidney & $18.8 \pm 8.7$ & $22.6 \pm 5.4$ & $19.1 \pm 1.7$ & $24.2 \pm 7.5$ & $19.6 \pm 5.4$ \\
\hline & Liver & $40.5 \pm 19.5$ & $42.3 \pm 14.5$ & $32.7 \pm 7.8$ & $53.0 \pm 21.1$ & $33.8 \pm 8.6$ \\
\hline
\end{tabular}


Table 2. Influence of age and specie on trace element concentrations in the liver (L) and kidney (K) of common dolphin (Delphinus delphis), pilot whale (Globicephala melas), harbour porpoise (Phocoena phocoena), striped dolphin (Stenella coeruleoalba) and bottlenose dolphin (Tursiops truncatus) from the North West Iberian Peninsula, determined using ANCOVA. Influence of the studied parameters is given with its associated $p$-value. ns: not significant influence.

\begin{tabular}{lccc}
\hline Trace element & & Explanatory variable/effects & Age $\times$ Species \\
\cline { 2 - 4 } & Age & Species & $P<0.01$ \\
AgL & $P<0.001$ & $P<0.001$ & $P<0.05$ \\
CdK & $P<0.001$ & $P<0.001$ & $P<0.001$ \\
CdL & $P<0.001$ & $P<0.001$ & $\mathrm{~ns}$ \\
CrK & $\mathrm{ns}$ & $P<0.001$ & $\mathrm{~ns}$ \\
$\mathrm{CrL}$ & $P<0.01$ & $P<0.001$ & $\mathrm{~ns}$ \\
$\mathrm{CuK}$ & $P<0.05$ & $\mathrm{~ns}$ & $\mathrm{~ns}$ \\
$\mathrm{CuL}$ & $\mathrm{ns}$ & $P<0.001$ & $\mathrm{~ns}$ \\
$\mathrm{FeK}$ & $P<0.05$ & $\mathrm{~ns}$ & $P<0.01$ \\
$\mathrm{FeL}$ & $\mathrm{ns}$ & $P<0.001$ & $P<0.01$ \\
$\mathrm{HgK}$ & $P<0.01$ & $P<0.001$ & $\mathrm{~ns}$ \\
$\mathrm{HgL}$ & $\mathrm{ns}$ & $P<0.05$ & $\mathrm{~ns}$ \\
$\mathrm{MnL}$ & $P<0.05$ & $P<0.01$ & $\mathrm{~ns}$ \\
$\mathrm{SeK}$ & $\mathrm{ns}$ & $P<0.001$ & $P<0.001$ \\
$\mathrm{SeL}$ & $P<0.001$ & $P<0.05$ & $P<0.05$ \\
$\mathrm{ZnK}$ & $\mathrm{ns}$ & $P<0.01$ & $\mathrm{~ns}$ \\
$\mathrm{ZnL}$ & $\mathrm{ns}$ & & \\
\hline
\end{tabular}


Table 3. Spearman rank correlation coefficients (r) between several non-essential and essential elements in the liver (L) and kidney (K) of common dolphin (Delphinus delphis), pilot whale (Globicephala melas), harbour porpoise (Phocoena phocoena), striped dolphin (Stenella coeruleoalba) and bottlenose dolphin (Tursiops truncatus) from the North West Iberian Peninsula. Significant values are in bold.

\begin{tabular}{lllllll}
\hline & HgL/SeL & HgK/SeK & CdL/CuL & CdK/CuK & CdL/ZnL & CdK/ZnK \\
\hline Delphinus delphis & $\mathbf{0 . 8 5 4 * * *}$ & $\mathbf{0 . 5 1 1} * * *$ & $\mathbf{0 . 2 0 3} *$ & 0.051 & -0.178 & 0.072 \\
Globicephala melas & $\mathbf{0 . 9 2 9} * *$ & 0.616 & 0.380 & 0.183 & 0.262 & 0.316 \\
Phocoena phocoena & $\mathbf{0 . 9 5 6 * * *}$ & 0.193 & 0.506 & 0.211 & 0.103 & 0.246 \\
Stenella coeruleoalba & $\mathbf{0 . 9 1 5 * * *}$ & $\mathbf{0 . 8 1 6} * * *$ & -0.046 & $\mathbf{0 . 2 3 5} *$ & $\mathbf{- 0 . 5 0 9 *}$ & $\mathbf{0 . 6 8 1} * *$ \\
Tursiops truncatus & $\mathbf{0 . 9 6 4 * *}$ & $\mathbf{0 . 9 7 6 * *}$ & -0.071 & 0.405 & 0.179 & 0.238 \\
\hline
\end{tabular}

$* 0.01<P<0.05$

$* * 0.001<P<0.01$

$* * * P<0.001$ 
Table 4. Mean \pm SD of hepatic $\mathrm{Hg}$ and renal Cd concentrations ( $\mu \mathrm{g} \mathrm{g}^{-1}$ wet weight) of the five toothed whale species from all over the world. Sample size " $n$ " of each species and area is in brackets. The average or ranges of age (years) and length (cm) are given when available.

\begin{tabular}{|c|c|c|c|c|c|}
\hline Species & Area & Age/Length & Total hepatic Hg & Renal Cd & References \\
\hline \multicolumn{6}{|c|}{ Delphinus delphis } \\
\hline & NE Atlantic Ocean & & & & \\
\hline & NWIP & $0-18$ & $10.4 \pm 31.8(100)$ & $2.3 \pm 2.7(98)$ & This study \\
\hline & Portugal & $180-210$ & $5.7 \pm 9.0(15)^{\mathrm{a}}$ & & Carvalho et al., 2002 \\
\hline & Portugal & $137-230$ & $11.0 \pm 18.3(22)$ & $0.5 \pm 0.3(4)$ & Zhou et al., 2001 \\
\hline & France & $3-18$ & $34.0 \pm 44.0(28)^{\mathrm{a}}$ & $3.0 \pm 4.4(20)^{\mathrm{a}}$ & Holsbeek et al., 1998 \\
\hline & France (Oceanic) & $<1-20$ & & $16.3 \pm 14.0(10)^{\mathrm{a}}$ & Das et al., 2000b \\
\hline & France (English channel) & & $35.9 \pm 45.2(5)^{\mathrm{a}}$ & $2.0 \pm 1.9(5)^{\mathrm{a}}$ & Das et al., 2003b \\
\hline & Ireland & & $13.3 \pm 15.9(8)^{\mathrm{a}}$ & $7.6 \pm 5.8(12)^{\mathrm{a}}$ & Das et al., 2003b \\
\hline & Ireland & & $15.3 \pm 23.0(7)$ & & Law et al., 1992 \\
\hline & British isles & & $11.0(1)$ & & Law et al., 1991 \\
\hline & Mediterranean Sea & & & & \\
\hline & France & 2 & $38.9(1)$ & & Frodello et al., 2000 \\
\hline & NW Atlantic Ocean & & & & \\
\hline & USA & $9 \pm 3$ & $26.0(3)$ & & Kuehl et al., 1994 \\
\hline & SW Atlantic Ocean & & & & \\
\hline & Brazil $^{*}$ & 213 & $23.0(1)$ & & Kunito et al., 2004 \\
\hline & Pacific and Indian Ocean & & & & \\
\hline & Australia & & $33.0-72.1(2)$ & $0-33.0(17)^{b}$ & Kemper et al., 1994 \\
\hline & South Australia & & $31.2 \pm 37.1(68)$ & & Lavery et al., 2008 \\
\hline & New Zealand & $8 \pm 2$ & $71.0 \pm 33.8(3)$ & $29.0 \pm 19.9(3)$ & Stockin et al., 2007 \\
\hline
\end{tabular}




\begin{tabular}{|c|c|c|c|c|c|}
\hline \multicolumn{6}{|l|}{ Globicephala melas } \\
\hline & NE Atlantic Ocean & & & & \\
\hline & NWIP & 0 - 11 & $31.0 \pm 59.5(8)$ & $23.9 \pm 26.9(6)$ & This study \\
\hline & Ireland & & $206.0(8)$ & $91.0(22)$ & Troisi et al., 1998 ; Das et al., 2000b \\
\hline & British isles & & $0.7(1)$ & & Law et al., 2001 \\
\hline & Faroe Islands & $15-31$ & $213.0 \pm 194.0(8)$ & $86.0 \pm 49.0(39)$ & Caurant et al., 1995, 1996 \\
\hline & Faroe Islands & matures & $280.0 \pm 100.0(8)$ & $6.2 \pm 2.6(6)$ & Julshamn et al., 1987 \\
\hline & Faroe Islands & & $138.0(7)$ & $36.0(7)$ & Sonne et al., 2010 \\
\hline & NW Atlantic Ocean & & & & \\
\hline & Canada & $7 \pm 6$ & $18.2 \pm 25.5(26)^{\mathrm{a}}$ & $17.8 \pm 14.5(26)^{\mathrm{a}}$ & Muir et al., 1988 \\
\hline & USA & & $40.3 \pm 38.8$ & & Mackey et al., 1995 \\
\hline & USA (Cumberland island) & $374 \pm 7$ & $231.0 \pm 172.0$ & $31.4 \pm 7.0(4)$ & Stoneburner, 1978 \\
\hline & Caribbean Sea* & & $88.7 \pm 67.9(5)$ & & Gaskin et al., 1974 \\
\hline & Pacific Ocean & & & & \\
\hline & New Caledonia* & $13 \pm 1$ & $318.0(2)$ & & Bustamante et al., 2003 \\
\hline \multicolumn{6}{|l|}{ Phocoena phocoena } \\
\hline & NE Atlantic Ocean & & & & \\
\hline & NWIP & 0 - 18 & $16.8 \pm 30.0(14)$ & $2.3 \pm 5.3(12)$ & This study \\
\hline & NW Spain & $<1-6$ & $1.2 \pm 0.3(3)$ & $0.1(2)$ & Lahaye et al., 2007 \\
\hline & France & $0-26$ & $17.9 \pm 21.9(13)$ & $1.4 \pm 1.4(13)$ & Lahaye et al., 2007 \\
\hline & Celtic Shelf & $0-23$ & $10.7 \pm 14.4(8)$ & $0.6 \pm 0.7(8)$ & Lahaye et al., 2007 \\
\hline & France (English channel) & & $2.6 \pm 3.2(4)^{\mathrm{a}}$ & $0.3 \pm 0.6(4)^{\mathrm{a}}$ & Das et al., 2003b \\
\hline & France (English channel) & $0-26$ & $10.7 \pm 14.3(8)$ & $0.6 \pm 0.7(8)$ & Lahaye et al., 2007 \\
\hline & Irish Sea & $0-11$ & $30.0 \pm 48.8(12)$ & $0.6 \pm 0.6(11)$ & Lahaye et al., 2007 \\
\hline & East Scotland & $110-170$ & $6.0 \pm 5.9(6)$ & $2.7 \pm 2.8(6)$ & Falconer et al., 1983; Wells et al., 1994 \\
\hline & NW Scotland & $0-12$ & $12.4 \pm 11.8(5)$ & $6.4(2)$ & Lahaye et al., 2007 \\
\hline
\end{tabular}




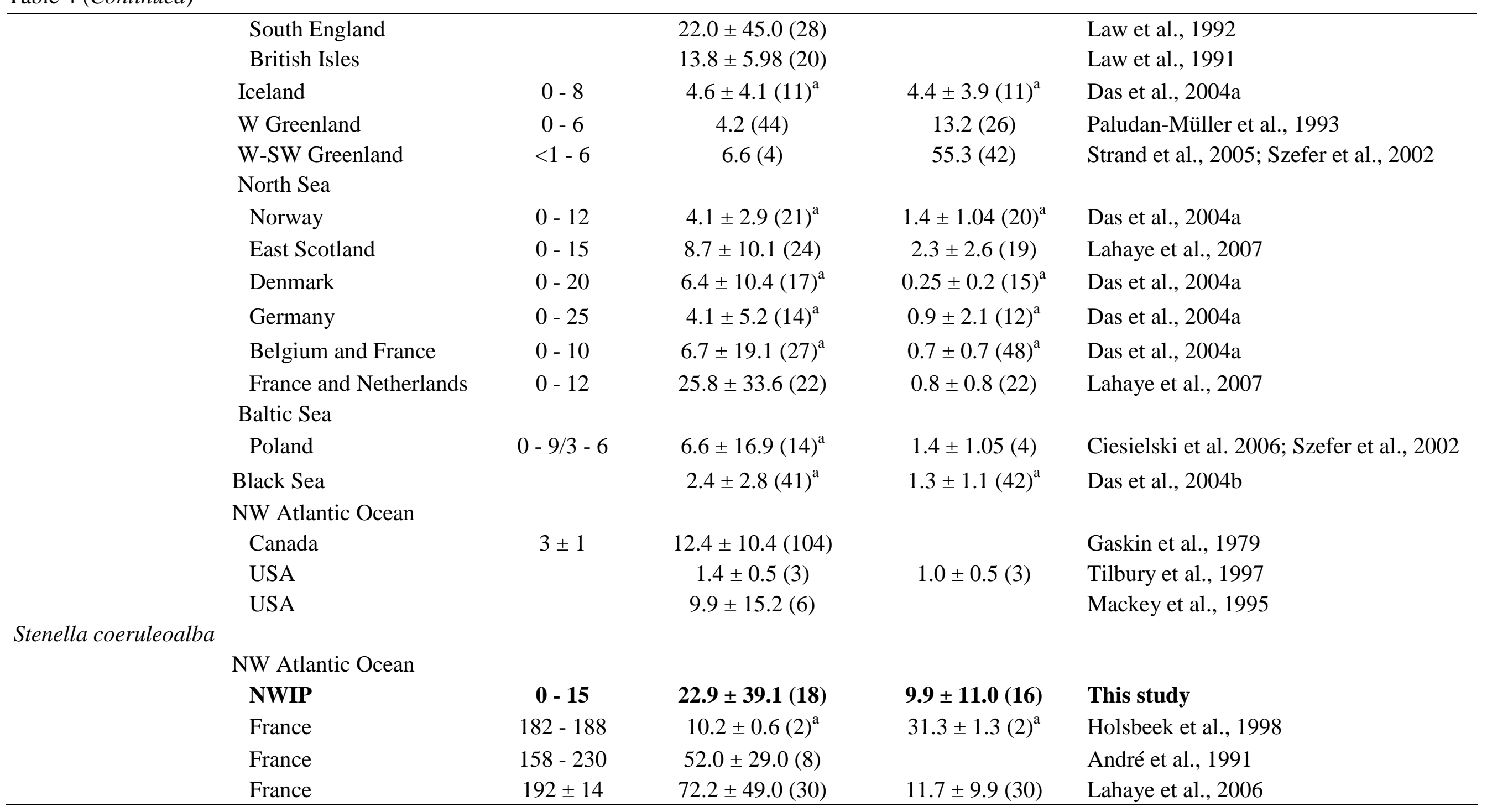




\begin{tabular}{|c|c|c|c|c|c|}
\hline & France (English channel) & & $10.7 \pm 7.2(3)^{\mathrm{a}}$ & $16.3 \pm 23.9(3)^{\mathrm{a}}$ & Das et al., 2003 \\
\hline & France (Oceanic) & $0.1-20$ & & $20.9 \pm 13.1(23)^{\mathrm{a}}$ & Das et al., 2000 \\
\hline & Ireland & & $11.9 \pm 9.0(2)^{\mathrm{a}}$ & $34.5 \pm 8.1(4)^{\mathrm{a}}$ & Das et al., 2003 \\
\hline & British Isles & & $8.9 \pm 2.8(3)$ & & Law et al., 1992 \\
\hline & England & & $20.0(1)$ & & Morris et al., 1989 \\
\hline & \multicolumn{5}{|l|}{ Mediterranean Sea } \\
\hline & Spain & $11 \pm 7$ & $302.5^{\mathrm{b}} \pm 242.2(34)^{\mathrm{a}}$ & $1.9^{\mathrm{b}} \pm 1.5(20)^{\mathrm{a}}$ & Monaci et al., 1998 \\
\hline & France & $184 \pm 31$ & $426.8 \pm 464.6(25)^{\mathrm{a}}$ & & André et al., 1991 \\
\hline & Italy & $7 \pm 6$ & $171.9^{\mathrm{b}} \pm 324.8(46)^{\mathrm{a}}$ & $6.3^{\mathrm{b}} \pm 7.2(39)^{\mathrm{a}}$ & Monaci et al., 1998 \\
\hline & South Italy & $160 \pm 24$ & $155.2 \pm 151.5(39)$ & $3.1 \pm 2.6(9)$ & Decataldo et al., 2004 \\
\hline & Israel & $178 \pm 37$ & $181.0 \pm 200.0(6)$ & $11.0 \pm 12.0(6)$ & Roditi-Elasa et al., 2003 \\
\hline & \multicolumn{5}{|l|}{ Adratic Sea } \\
\hline & Croatia & $05-11$ & $185.0 \pm 209.2(2)$ & & Pompe-Gotal et al., 2009 \\
\hline & \multicolumn{5}{|l|}{ SW Atlantic Ocean } \\
\hline & Brazil & 8 & $290.0(1)$ & & Kunito et al., 2004 \\
\hline & Brazil $^{*}$ & $86-200$ & $40.3 \pm 19.2(3)$ & & Lemos et al., 2013 \\
\hline & \multicolumn{5}{|l|}{ Pacific Ocean } \\
\hline & California * & $180 \pm 8(13)$ & $28.5 \pm 13.8(13)^{\mathrm{a}}$ & & Ruelas and Páez-Osuna, 2002 \\
\hline & Japan & & $205.0(45)$ & $24.8(30)$ & Honda et al., 1983 \\
\hline & Japan & & $5.8 \pm 2.8(6)$ & & Itano et al., 1984 \\
\hline \multirow[t]{3}{*}{ Tursiops truncatus } & \multicolumn{5}{|l|}{ NE Atlantic Ocean } \\
\hline & NWIP & $3-7$ & $19.1 \pm 22.4(8)$ & $5.8 \pm 13.8$ & This study \\
\hline & Portugal & $254-327$ & $37.0 \pm 34.0(2)^{\mathrm{a}}$ & & Carvalho et al., 2002 \\
\hline
\end{tabular}




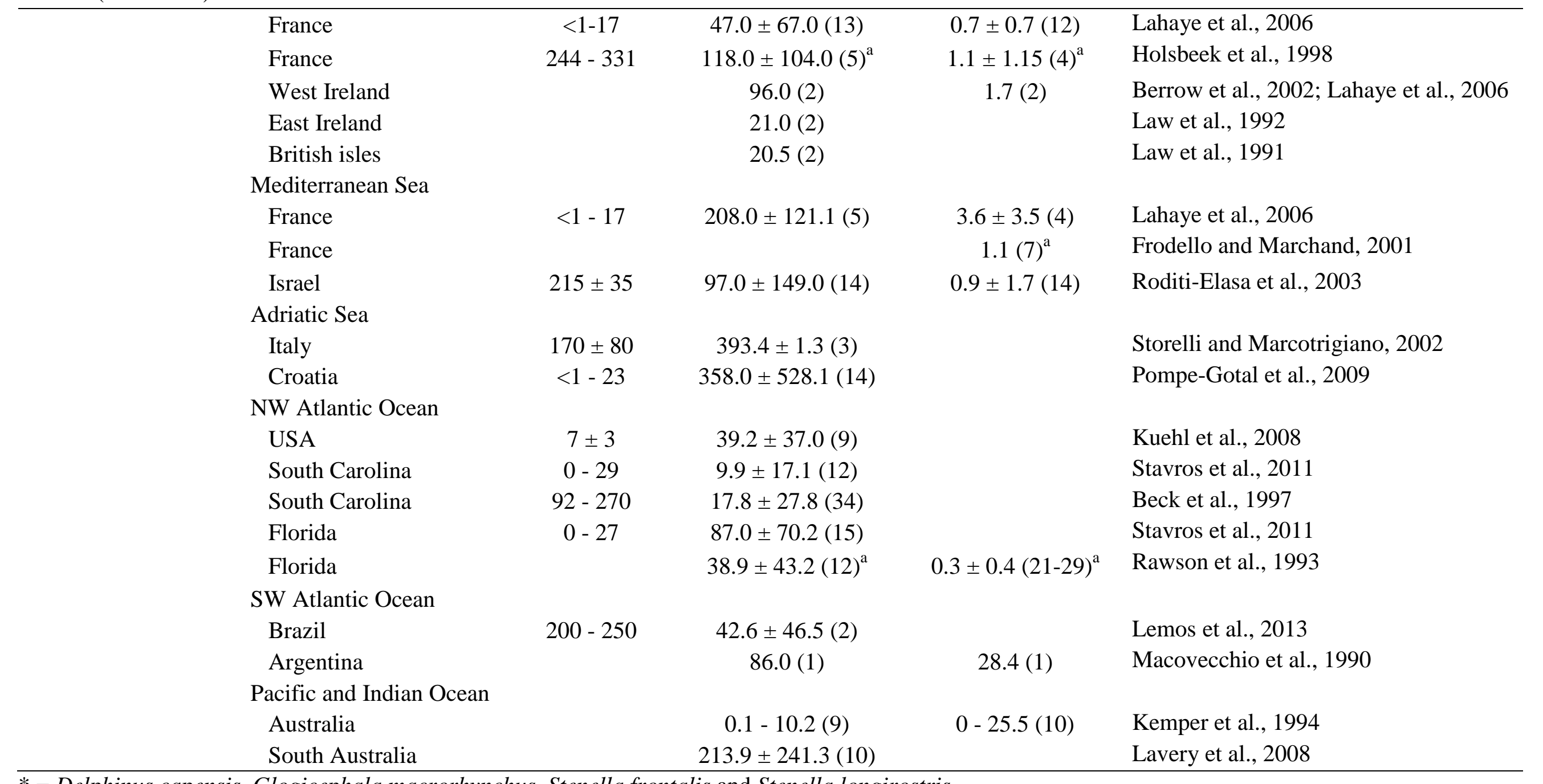

* = Delphinus capensis, Glogicephala macrorhynchus, Stenella frontalis and Stenella longirostris

${ }^{a}$ dry weight converted in wet weight on the basis of the dry wet weight:wet weight ratio obtained during this study

${ }^{\mathrm{b}}$ Range or median 